IBAD Sosyal Bilimler Dergisi

IBAD Journal of Social Sciences

dergipark.org.tr/ibad

IBAD, 2021; (11): 366-393

DOI: $10.21733 /$ ibad.947566

Özgün Araştırma / Original Article

\title{
Türk Müziği Destekli Psikolojik Sağlamlık Programı: Okul Öncesi Dönemdeki Çocukların Psikolojik Sağlamlık Düzeyleri Üzerine Etkisi
}

\section{Psychological Resilience Program Assisted by Turkish Music: The effect on the Psychological Resilience Level of Preschool Children}

\section{Semanur Cömert ${ }^{1 *}$}

Prof. Dr. Saide Özbey ${ }^{2}$

\section{* Sorumlu yazar \\ Corresponding author}

1 Öğretmen, MEB, Türkiye

Teacher, Ministry of Education,Turkey

sema.kindergarden@gmail.com, semanurrcomert@gmail.com

ORCID ID 0000-0002-5051-7521

${ }^{2}$ Prof. Dr., Gazi Üniversitesi, Turkey

Prof. Dr., Gazi University, Turkey

saideozbey@gmail.com, sozbey@gazi.edu.tr

ORCID ID 0000-0001-8487-7579

Makale geliş tarihi / First received : 03.06.2021

Makale kabul tarihi / Accepted : 28.07.2021

\section{Bilgilendirme / Acknowledgement:}

1- Makale, Gazi Üniversitesi / Eğitim Bilimleri Enstitüsü / Okul Öncesi Eğitimi Anabilmdalı'nda ikinci yazarın danışmanlığında birinci yazarın doktora tezinden üretilmiştir.

2- Makale, 2.Uluslararası Bakü Bilimsel Araştırmalar Kongresi'nde 28-30 Nisan 2021 tarihleri arasında sunulmuş bildirinin genişletilmiş ve gözden geçirilmiş hâlidir.

3- Araştırmaya katılımcı olarak destek veren öğrencilere ve öğretmenlere teşekkür ederiz.

4- Araştırmanın yapıldığı İl Milli Eğitim Müdürlüğünün 11.11.2020 tarihli ve 27001677-44-E.16541683 sayılı yazısı ile gerekli izinler alınmıştır.

5- Makaledeki deneysel çalışmalar, uluslararası deklerasyon, kılavuz vb.'ye uygun gerçekleştirilmiştir.

6- Bu makalede araştırma ve yayın etiğine uyulmuştur.

This article was checked by Turnitin. Similarity Index 23\%

Atıf bilgisi / Citation: Cömert, S., Özbey, S. (2021). Türk müziği destekli psikolojik sağlamlık programı: Okul öncesi dönemdeki çocukların psikolojik sağlamlık düzeyleri üzerine etkisi. IBAD Sosyal Bilimler Dergisi, (11), 366-393. 
ÖZ

Araştırmanın amacı, Türk Müziği Destekli Psikolojik Sağlamlık Programı'nın okul öncesi dönemdeki çocukların psikolojik sağlamlık düzeylerine etkisini incelemektir. Araştırmada ön test-son test kontrol gruplu deneysel desen kullanılmıştır. Araştırmanın çalışma grubunu Tokat il merkezinde Milli Eğitim Bakanlığı'na bağlı ilkokulların anasınıflarına devam eden tesadüfi örnekleme yöntemi ile seçilmiş 48-72 aylık 21 çocuk oluşturmaktadır. Program öncesinde çocukların psikolojik sağlamlık düzeyleri ölçülmüş, yapılan analizler sonucunda aralarında anlamlı farklılık olmayan ve puanları birbirine yakın olan biri kontrol iki deney olmak üzere üç grup belirlenmiştir. Araştırmada veri toplama aracı olarak çocukların psikolojik sağlamlık düzeylerini ölçmek amacıyla "'Okul Öncesi Çocuklar İçin Sosyal Duygusal İyi Oluş ve Psikolojik Sağlamlık Ölçeği" kullanılmıştır. Araştırmada araştırmacı tarafından uzman görüşleri alınarak son hali verilen bütünleştirilmiş 30 etkinlikten oluşan, "Psikolojik Sağlamlık Programı" uygulanmıştır. Psikolojik sağlamlık programı iki deney grubuna da uygulanmıştır. 2. deney grubunda Psikolojik Sağlamlık Programı'na Türk müziği eserleri de entegre edilmiştir. Kontrol grubunda ise sadece Milli Eğitim Bakanlığı Müfredatı uygulanmıştır. Türk Müziği Destekli Psikolojik Sağlamlık Programı haftada 5 gün ve 4 hafta süreyle uygulanmıştır. Araştırma sonucunda, kontrol grubuna göre son test puanlarının her iki deney grubunun lehine anlamlı farklılık gösterdiği saptanmıştır. Bununla birlikte Müzikli Deney Grubu ile Müziksiz Deney Grubu'nun son test puanları arasındaki farkın Müzikli Deney Grubu lehine olduğu saptanmıştır. Başka bir ifadeyle çocuklara uygulanan Psikolojik Sağlamlık Programı'nın çocukların psikolojik sağlamlık düzeylerine anlamlı katkı sağladığı; Türk müziğinin kullanılmasınin ise programin etkisini anlamlı düzeyde artırdığı ifade edilebilir.

\section{Anahtar Kelimeler}

Psikolojik Sağlamlık, Türk Müziği, Okul Öncesi.

\section{ABSTRACT}

The aim of the study is to examine the effect of the Psychological Resilience Program Assisted by Turkish Music on the psychological resilience levels of preschool children. The pre-test post-test control group experimental design was used in the study. The working group of the study consisted of 21 randomly selected preschool children in the ages between 48 to 72 months attending to nursery classes of schools in the centre of the Tokat province under the Ministry of National Education. Before the program, the psychological resilience levels of children were measured and three groups including one control group and two experiment groups were determined upon analysis wherein the groups had no significant differences between them and had similar scores. "The Emotional Well-being and Psychological Resilience Scale for Preschool Children" was used in order to measure the psychological resilience levels of children as the data collection tool in the study. The "Psychological Resilience Program" consisting of 30 integrated activities that were finalized by the researcher with expert views was applied in the study. The psychological resilience program was applied to both experiment groups. In the control group, only the curriculum of the Ministry of National Education was applied. Pieces of Turkish Music were integrated into the psychological resilience program in the 2nd experiment group. Psychological Resilience Program Assisted by Turkish Music was applied for 5 days throughout 4 weeks. As a result of the research, it was determined that the postest scores of the two experiment groups were significantly different than the control group. On the other hand, it was determined that the difference between the posttest scores of the Experiment Group with Music and the Experiment Group without Music was in favour of the Experiment Group with Music. In other words, it can be said that the psyshcological resilience program applied to children had a significant contribution on their psyshcological resilience levels and that the use of Turkish Music increased the effect of the program significantly.

\section{Keywords}

Psyshcological Resilience, Turkish Music, Preschool. 


\section{GİRIŞ}

Çocuklar günlük yaşamlarında karşılaştıkları zorluklar ve ailelerinin yaşayabileceği stresli yaşam durumlarından doğrudan etkilenirler (Oades-Sese, Cohen, Allen ve Lewis, 2014). Bu nedenle her yaştan çocuklar, travma sonrası stres, depresyon veya diğer zihinsel sağlık sorunlarının kısa veya uzun vadeli semptomlarına neden olabilecek felaketlere maruz kaldıklarında savunmasızdır (Osofsky ve Osofsky, 2018, s.5). Günümüz çocukları ise önceki nesillerle karşılaştırıldığında, kısmen zorlayıcı fırsatlardan korunmaları nedeniyle stres etkenleri ve engellerle daha az başa çıkabildikleri ve zorlukların üstesinden gelebilme becerilerinin daha düşük düzeyde olduğu görülmektedir. Son yarım yüzyılda çoğu gelişmiş ülkede çocukların psikolojik ve davranış bozukluklarında önemli bir artışın meydana geldiğine dair yaygın bir fikir birliği vardır. Bu durum, İsveç gibi çok beğenilen yüksek sosyal refah sistemlerine sahip ülkelerde bile mevcut bir eğilimdir (Newman ve Blackburn, 2002). Gelişmekte olan bir çocuğun zorluklara ve olumsuzluklara cevap verme kapasitesi, nörobiyolojik stres düzenleme sistemlerinden ailelere, okullara, toplum güvenliği ve sağlık bakım sistemlerine ve çok sayıda diğer sosyokültürel ve ekolojik sistemlere kadar birçok sistemin çalışmasına bağlıdır (Masten, 2019). Duygular ve davranış arasındaki ilişkiyle ilgili son teoriler, bir bireyin sosyal davranış biçiminin duygusal deneyimden ve beklentisinden etkilendiğini vurgulamaktadır (Mihaelaa, 2015). Sosyal ve duygusal beceride yetkin olan çocuklar, yaşamın her alanında diğerlerine göre daha başarılı olmaktadır (Schilling, 2009, s.29). Okul öncesi yıllar çocukların duygusal gelişimi için oldukça önemlidir. Örgün eğitimin başlamasıyla birlikte çocuklara yeni bilişsel, sosyal ve davranışsal talepler sunulduğundan, önemli bir geçiş dönemidir. Çocuklar büyüdükçe, bu talepler artmaya devam eder, bu da çocukların okul öncesi dönemde erken gelişimsel görevlerde ustalaşamazlarsa akranlarına yetişmesini ve yeni akademik ihtiyaçları karşılamasını gittikçe zorlaştırır (Yule, 2017, s.1; Zhang, Wu, Qu, Wang, Wu, Tang, Liu, Chen, Zhao, Xuan ve Sun, 2020). Çocukları, doğru ve esnek düşünmeyi destekleyen psikolojik sağlamlık becerileriyle tanıştırmak, onları kaçınılmaz güçlüklerle başa çıkmaya hazırlamaya ve onları depresyona karşı aşılamaya yardımcı olabilir (Kordich Hall ve Pearson, 2005). Bu nedenle, okul öncesi çağındaki çocuklarda psikolojik sağlamlığın nasıl teşvik edileceğini, geliştirileceğini anlamak, uyarlanabilir işlevselliği ve erken akademik başarıyı desteklemek için önemlidir (Yule, 2017, s.1). Bireylerin hem insan yapımı hem de doğal afetler de dahil olmak üzere zorluklarla başa çıkma, üstesinden gelme, güçlenme ve hatta bu deneyimler tarafından dönüştürülme kapasitesi vardır (Henderson-Grotberg, 2001). Bu insan kapasitesi psikolojik sağlamlık olarak ifade edilmektedir.

Psikolojik sağlamlık, önemli stres veya travma kaynaklarını etkili bir şekilde müzakere etme, bunlara uyum sağlama veya yönetme sürecidir (Werner, 1997). Psikolojik sağlamlık, etkili başa çıkma becerisine sahip olmaktır. Önemli tehdit altında, düşünce ve eylem de dahil olmak üzere insan faaliyetleri aracıllğıyla iç veya dış dengeyi yeniden tesis etme veya sürdürme çabaları anlamına gelir (Masten, Best ve Garmezy, 1990). Masten (2014), bunu daha spesifik olarak "Dinamik bir sistemin işlevini, yaşaya bilirliğini veya gelişimini tehdit eden rahatsızlıklara başarılı bir şekilde uyum sağlama kapasitesi" şeklinde tanımlamıştır (s.10). Literatürde psikolojik sağlamlık tanımlarının çoğu iki unsur içerir. Birincisi, olumsuz veya travmatik koşullara maruz kalma; ikincisi ise maruz kalmanın ardından başarılı bir adaptasyondur (Maier, Vitiello, ve Greenfield, 2012; Mihaela, 2015; Miljević-Riđički, Plantak ve Bouillet, 2017). Dirençli çocuklar hakkında en önemli sorulardan birisi, diğer çocuklar 
zorluklarla karşılaştığında bocalarken dirençli çocukların zorlukların üstesinden gelmelerini sağlayan benzersiz veya özel bir şeyin olup olmadı̆̆ıdır (Maier vd., 2012). Masten ve Barnes (2018), diğerleri çırpınırken ya da parçalanırken, bazı insanların nasıl iyileştiğini ya da geliştiğini açıklayabilecek şeyin, koruyucu faktörler olduğunu belirtir. Strese dayanıklı, yenilmez ve daha yakın zamanda esnek olarak adlandırılan bu çocukların, bazı güçlü yanlara sahip oldukları ve olumsuz koşulların üstesinden gelmelerine ve kendilerini geliştirmelerine yardımcı olan koruyucu etkilerden yararlandıkları tespit edilmiştir. Bir çocuğun zekâsı, arkadaş edinme başarısı ve davranışını düzenleyebilme yeteneği, psikolojik sağlamlığı geliştiren içsel güçlere örnektir. Dayanıklılığı artıran dış etkenlere örnek olarak yetkin ebeveynler, arkadaşlıklar, destek ağları ve etkili okullar verilebilir (Alvord ve Grados, 2005). Garmezy ve Masten (1986), eğitimin psikolojik sağlamlık için koruyucu bir faktör olduğunu, eksikliğinin ise riskle özdeşleştirildiğini belirtmişlerdir. Okul öncesi yıllar, okula hazır bulunuşluğu destekleyen sinir sistemlerinin, davranışların ve sosyal sistemlerin hızlı bir şekilde geliştiği bir dönemdir. Ebeveynler öğretmenlerle birlikte, yaşam boyunca sağlıklı gelişimi destekleyen ve dayanıklılık için insan kapasitesi oluşturan sistemleri beslemede son derece önemli liderlik rolleri oynarlar (Masten ve Barnes, 2018). Sıkıntı içinde büyüyen çocuklarla ilgili çeşitli boylamsal araştırmalar, besleyici bir okul ikliminin çocukların hayatındaki inanılmaz risk faktörlerinin üstesinden gelme gücüne sahip olduğunu göstermektedir (Benard, 1993). Maier vd. (2012) okul öncesi eğitim gören çocuklar için sınıf, psikolojik sağlamlı̆̆1 teşvik etmede benzersiz bir role sahip olabilecek özellikle önemli bir çevresel bağlam olduğunu vurgulamıştır. Bailey, Zinsser, Curby, Denham ve Bassett (2013)'e göre okul öncesi sınıfları, çocukların duyguları etkili bir şekilde iletme, duygusal deneyimleri yönetme ve sinir bozucu durumlarda prososyal bir şekilde tepki verme gibi sosyal-duygusal becerileri geliştiren laboratuvarlardır. Okul öncesi sınıflarında öğretmenler ve çocuklar arasındaki sosyal-duygusal etkileşimler, anaokulunda ve sonrasında başarılı öğrenme deneyimlerine zemin hazırlar. Araştırmalar, psikolojik sağlamlığın bir çocuğun hayatının erken dönemlerinde gelişmeye başladığını göstermektedir (Werner, 1993; Masten ve Coatsworth, 1998). Werner' in (1993) koruyucu faktörlerin ve süreçlerin uzun vadeli etkilerini incelediği çalışmaları, yetişkin sonuçlarının en kritik belirleyicilerinden bazılarının yaşamın ilk on yılında mevcut olduğunu göstermiştir. Mihaela (2015), çocukluk döneminde güçlü bir sosyal-duygusal temel oluşturmanın, çocukların hayatta başarılı ve mutlu olmalarına yardımcı olacağını, yetişkin olduklarında stresi yönetmeye ve zorlukların önünde sebat etmeye daha hazırlıklı olacaklarını belirtmektedir. Küçük çocuklara yönelik en büyük tehdit, insani gelişme için temel koruyucu sistemler zarar gördügünde veya bozulduğunda ortaya çıar. Erken çocukluğun psikolojik sağlamlı̆̆ı anlamak ve geliştirmek için önemli bir zaman penceresi olduğu açıktır. Bu yıllarda yetkinlik kökleri kurulur ve insan gelişimi için en önemli koruyucu sistemlerin çoğu ortaya çıkar. Bu erken yıllar, riski önleme ve azaltma, kaynakları artırma, yetkinliği arttırma ve gelecekteki gelişim için güçlü bir temel oluşturma konusunda yapilan müdahaleler için büyük umut vaat etmektedir (Masten, Gewirtz ve Sapienza, 2013).

Psikolojik sağlamlığı geliştiren, akademik ve sosyal yeterliliği artıran koruyucu faktörler arasında müzik, geçmiş çağlardan beri önemli bir yere sahiptir. İnsan hayatının her döneminde rahatlatıcı bir güç olduğuna inanılan müzik, insanın ruh sağlığında önemli bir yer tutar (Gençel, 2006). Eski zamanlardan beri müzik insanları etkilemiş; şifa, terapi, hipnoz olarak kullanılmış ve birçok hastalığa müzik yoluyla çare aranmıştır (Sezince, 2018). Yunan'lı 
Filozof Platon (M.Ö. 427-348) 'a göre, "Müzik insan ruhunu sakinleştiren sanattır, müzik eğitimi insanı yüceltir, düzeni sağlamaktadır." Platon, ruhun eğitiminde başvurulabilecek en etkili vasıtanın müzik olduğunu belirtmektedir. Çinli filozof Konfüçyüs ise (M.Ö. 571-479) şöyle söylemektedir: "Hayat, 1stırap ve keder verirse sükûneti müzikte arayınız. Müzik gökle toprak arasında bir ahenktir" (Belgin, 2014). İbn-i Sina ise (980-1037), müzikle ilgili düşüncelerini, "Tedavinin en iyi yollarından, en etkililerinden biri, hastanın akli ve ruhi güçlerini arttırmak, ona hastalıkla daha iyi mücadele için cesaret vermek, ona en iyi musikiyi dinletmek, onu sevdiği insanlarla bir araya getirmektir..." şeklinde ifade etmektedir (Alkaya Yener, 2011; Ekici, 2014; Güvenç, 2014). Müzik kulağa hitabeden, çok güçlü bir etkiye sahip, ses üzerine kurulmuş, güzel sanatların önemli bir dalı olan sanat ilmidir. Müzik, sezgisel anlayışı; ruhsal ve bedensel iyileştirmeyi sağlar (Kalender, 1998). Gençel (2006), müziğin bazı hastalarda tedavi aracı olarak kullanılmasının yanı sıra, koruyucu bir faktör olarak da kullanılabileceğini belirtmektedir. Örneğin günlük hayatta insanları olumsuz etkileyen stres faktörünün ortadan kaldırılabilmesi için seçilecek uygun müzik türleri, kimi rahatsızlıkların oluşmasını engelleyecektir. Bu yüzden, hastalıklar oluşmadan, koruyucu niteliğinde kullanılmaya başlanması önerilmektedir. Düzenli olarak müzik dinleyen küçük çocuklar, dinlemeyenlere göre daha iyi gelişim gösterirler. Çocuklar büyüdükçe müzikle olan ilişkileri sayesinde sosyal, bilişsel ve fiziksel becerileri geliştirilebilir (Mattar, 2013). Müzik, çocuğa kendini ifade etme aracı ve duyguları için bir çıkış olanağı sağladığı için çocuğun eğitim ihtiyaçlarını karşılamada önemli bir rol oynayabilir (Dumont, Syurina, Feron ve van Hooren, 2017). Müzik, çocukların başta işitme olmak üzere tüm duyularını uyarır. Ayrıca çocukların farklı görevler sırasında dikkatlerini korumalarına yardımcı olarak konsantrasyon becerilerini geliştirir. Müziğin tüm bu faydaları bilişsel yeteneklerin gelişmesinde önemlidir. Müzik, düşünmeye giden en doğrudan yol olarak kabul edilir, çünkü algılanmak için ne kelimelere ne de sembollere ihtiyaç duyar. (Snyder, 1997). Müzik, herhangi bir eğitim ortamının önemli bir parçası olabilir. Müzik, sakinlik ve rahatlama sağladığı için anaokulundaki çocukların sosyal gelişimini artırır, dürtüselliği azaltır (Mattar, 2013). Bir sinirbilimci olan Frank Wilson, çocukların belirli görevleri yerine getirirken beyin taramalarını gözlemlemiş; çocuklar kelimeleri okuduğunda, tarayıcısında beynin dil merkezinin aydınlandığını, ancak müzik duyduklarında tüm beynin aydınlandığını ifade etmiştir (Snyder, 1997). Alkaya Yener'e (2011) göre, Klasik Türk müziğinin çocuklar üzerindeki olumlu ve uyarıcı etkileri bulunmakla birlikte, çocukların müzikle erken yaşlarda tanışmasına ve bu alışkanlığın ömür boyu devam ettirilmesine ortam hazırlanmalıdır. İnsan beyninin en hızlı öğrenme dönemi 0-6 yaş arasıdır. Çocukların bu süreçte tüm doğru müzik seslerini tanıması gelecekleri için en büyük kazançtır (Belgin, 2014). Çocuklar müzik dinlerken legolarla oynayabilir, şarkıya eşlik edebilir, dans edebilir. Bu onlara aynı anda birden çok iş yapma ve ikili işlem gibi konularda erken yaşlarda deneyim sağlar. Bu şekilde, beyinlerindeki pek çok farklı ağı çalıştırmış olurlar (Andreasen, 2015, s.228). Müzikle ruhsal doyum sağlayan çocukların, daha sağlıklı bir kişilik yapısı kazanma olasılığı daha yüksektir (Uluğbay, 2013). Bu nedenle, müziğin sosyal-duygusal gelişimi ve psikolojik sağlamlığı destekleyici bir etkisi bulunmaktadır. Dillon (2006) çalışmasında, müzik yapımının, yaratıcı etkileşim fırsatları, kendi kendini motive eden davranışı teşvik etme, toplulukla etkileşim kurma, kültürel olarak kapsayıcı olma, analitik ve sezgisel bilgi arasında pozitif bir ilişki sergileme gibi koruyucu özellikler oluşturduğunu belirlemiştir (Akt; Price, 2011, s.24). Campbell, Connell ve Beegle (2007), müzik ve müzik katılımının geniş bir öğrenci popülasyonu arasında duygusal faydaları, yaşama faydaları ve sosyal faydaları olduğundan 
söz etmiştir. Sells ve Shepard (1998) müziğe katılımı, özel eğitim popülasyonlarında psikolojik sağlamlığı geliştirmeye yardımcı olabilecek çeşitli okul merkezli koruyucu faktörlerden biri olarak belirtmiştir (Akt; Price, 2011, s.24). Çalışmalar, müziğin psikolojik sağlamlığı teşvik etmede birçok olası koruyucu faktörden biri olduğunu göstermektedir.

The Over-Scheduled Child (Aşırı Programlı Çocuk) kitabında, gerçek yaşam tüm çabaya rağmen, er ya da geç kötü bir olay olduğunda, özenle korunan çocukların zorluklarla baş etmede savunmasız kalacaklarını yazmaktadır (Twenge, 2013, s.310). Ancak küçük çocuklara ilgili bakım ve destek sunulduğunda, en iyi uygulamaları bularak onlara daha esnek olmalarına yardımcı olma fırsatı her zaman vardır. Çocukların güçlükler veya aksiliklerle başa çıkarken sahip oldukları duygulara saygı duyarak ve güçlü yönlerini belirleyerek, "kendini toparlama" veya dirençli olmalarına yardımcı olmada rol olunabilir. Çağdaş bir psikolojik sağlamlık uzmanı olan Dr. Ken Ginsburg, psikolojik sağlamlığın dördüncü "R" olabileceğini, "Reading", "Riting" ve "Rithmetic" (okuma-yazma-sayma) kadar öğretiminin önemli olduğunu yazmıştır (Petty, 2014). Çocuklar hayatın önündeki engellerle etkili bir şekilde baş etmeyi öğrenebilir ve sistematik ve sürekli beceri geliştirme yoluyla depresyona karşı korunabilirler (Kordich Hall ve Pearson, 2005). Bu düşüncelerden hareketle bu araştırma, Türk Müziği Destekli Psikolojik Sağlamlık Programı'nın okul öncesi dönemdeki çocukların psikolojik sağlamlık düzeylerine etkisini incelemek amacıyla planlanmıştır. Araştırma, çocukların psikolojik sağlamlık düzeylerini geliştirebilmek için Türk müziği ve psikolojik sağlamlık programının önemine vurgu yapmak açısından önem taşımaktadır.

Literatür taraması yapıldığında Türk Müziği Destekli Psikolojik Sağlamlık Programı'nın okul öncesi dönemdeki çocukların psikolojik sağlamlık düzeylerine etkisini inceleyen bir araştırmanın olmadığı görülmüştür. Ancak yapılan araştırmalar incelendiğinde çocuklarda psikolojik sağlamlık becerisinin erken yıllarda kazandırılması ve bununla ilgili programların geliştirilmesinin önemi birçok araştırmacı tarafından vurgulanmaktadır. Psikolojik sağlamlığı artıran programlar, küçük çocukların güçlüklerle nasıl başa çıkacaklarını öğrenme şansı varsa, daha donanımlı olacaklarını ve gelecekte problemler ve krizlerle başa çıkmak için gerekli araçlara sahip olacaklarını söylemektedir (Sikorska ve Paluch, 2016). Her çocuğun psikolojik sağlam olma kabiliyeti olduğu ve küçük çocuklar zorluk ve stresle başa çıkmak için ne kadar iyi donatılırlarsa, başarılı olma olasılıklarının o kadar artacağı belirtilmektedir (Oades-Sese vd., 2014). Psikolojik sağlamlığı teşvik eden programlar, çocukların gelişimini desteklemek için tasarlanan programların bilişsel gelişim dışındaki alanlara odaklanabileceğini de göstermektedir. İç kaynakları harekete geçiren ve uyarlanabilir mekanizmalar geliştiren faaliyetler de müfredatın önemli bir parçası olabilir (Sikorska ve Paluch, 2016). Bu nedenlerle, bu çalışma Türk Müziği Destekli Psikolojik Sağlamlık Programı'nın okul öncesi dönemdeki çocukların psikolojik sağlamlık düzeylerine etkisini inceleyen ilk araştırma olması bakımından önem taşımaktadır. Araştırmanın Türk müziği ve psikolojik sağlamlık programının çocukların psikolojik sağlamlığına olumlu etkisine dikkat çekerek program geliştirme çalışmaları açısından eğitimcilere ve araştırmacılara rehber olacağı düşünülmektedir.

Araştırmada "Türk müziği destekli ve Türk müziği kullanılmayan psikolojik sağlamlık programlarının okul öncesi dönemdeki çocukların psikolojik sağlamlıkları üzerindeki etkisi ne düzeydedir?"' sorusuna cevap aranmıştır. 


\section{YÖNTEM}

\section{Araştırma Modeli}

Türk Müziği Destekli Psikolojik Sağlamlık Programı'nın okul öncesi dönemdeki çocukların psikolojik sağlamlık düzeylerine etkisini incelemek amacıyla yapılan bu çalışma karma modelin (mix research) kullanıldığı bir araştırmadır. Karma model, araştırmacıların açık uçlu sorular kullanarak nitel ve ölçekler kullanarak nicel veriler topladığı; her iki veri setini bütünleştirdiği ve sonuçlara ulaştı̆̆ araştırma yaklaşımıdır (Creswell, 2017). Bu doğrultuda karma modelin nitel araştırma boyutunda temel nitel araştırma desenlerinden durum çalışması kullanılırken (Yıldırım ve Şimşek, 2011); nicel araştırma boyutunda deneysel desen (Büyüköztürk, Çakmak, Akgün, Karadeniz ve Demirel, 2017) seçilmiştir.

\section{Çalışma Grubu}

Araştırmanın çalışma grubunu 2020-2021 eğitim-öğretim yılı güz döneminde, Tokat il merkezinde tesadüfi örnekleme yöntemi ile seçilen Milli Eğitim Bakanlığı'na bağlı farklı ilkokulların anasınıflarına devam eden 48-72 aylık 21 çocuk oluşturmaktadır. Araştırma öncesi, İl Milli Eğitim Müdürlüğünün 11.11.2020 tarihli ve 27001677-44-E.16541683 sayılı yazısı ile gerekli izinler alınmıştır. Araştırmaya katılan çocukların \%23,8'inin (5 kişi) müzikli deney grubunda, \%42,9'unun (9 kişi) müziksiz deney grubunda ve \%33,3'ünün (7 kişi) kontrol grubunda yer almıştır. Araştırmaya katılan çocukların \%4,8'i (1 kişi) kız, \%95,2'si ise erkektir.

\section{Veri Toplama Araçları}

Araştırmada, çocukların psikolojik sağlamlık düzeylerini ölçebilmek için “Okul Öncesi Çocuklar İçin Sosyal Duygusal İyi Oluş ve Psikolojik Sağlamlık Ölçeği” ve Psikolojik Sağlamlık Programı'nın ve Türk müziğinin etkisine yönelik sorulardan oluşan "Öğretmen Görüşme Formu " kullanılmıştır.

\section{Okul Öncesi Çocuklar İçin Sosyal Duygusal İyi Oluş ve Psikolojik Sağlamlık Ölçeği}

Mayr ve Ulich (2009) tarafından geliştirilen "Sosyal Duygusal İyi Oluş ve Psikolojik Sağlamlık Ölçeği'nin yurt içinde geçerlik güvenirlik çalışması Özbey (2019) tarafından 36-72 aylık 342 çocuk ile yapılmıştır. Ölçek her çocuk için kendi öğretmeni tarafından çocuk adına doldurulmaktadır. Ölçek 5’li Likert tipi bir ölçek olup; İletişim Kurma/Sosyal Performans, ÖzKontrol/Düşüncelilik, Atılganlık, Duygusal İstikrar/Stresle Başa Çıkma, Görev Yönelimi, Keşfetmekten Hoşlanma olmak üzere 6 alt ölçekten oluşmaktadır. Ölçekten toplam puan elde edilmemektedir. Alt ölçeklerin her birisinden elde edilen puanlar ayrı ayrı değerlendirilmektedir. Ölçeğin İletişim Kurma/Sosyal Performans alt ölçeğinde; olumlu iletişim kurma, kendini ifade etme, arkadaşlık kurabilmeye yönelik, Öz-Kontrol/Düşüncelilik alt ölçeğinde; öz-kontrol, kurallara uyma, saygı, nezaket, empati, düşünceli olmaya yönelik, Atılganlık alt ölçeğinde; girişkenlik, kendini ifade etme, özgüven, problem çözmeye yönelik, Duygusal İstikrar/Stresle Başa Çıkma alt ölçeğinde; duygu kontrolü, olumsuz bir durum sonrası kendini toparlama, stresle başa çıkmaya yönelik, Görev Yönelimi alt ölçeğinde; göreve yönelme, verilen görevi yerine getirme, dikkatini yoğunlaştırma, sorumluluğa yönelik, Keşfetmekten Hoşlanma alt ölçeğinde ise yenilikten ve keşfetmekten hoşlanma, merak, iyimser 
olma, özgüven, cesaret ve sabırlı olmaya yönelik maddeler yer almaktadır. Ölçeğin İngilizce ve Türkçe formları arasındaki Pearson Korelasyon Katsayısının .96 ile .99 arasında olduğu saptanmıştır. Ölçeğin Alpha güvenirlik katsayısı 36-48 aylık çocuklarda .72 ile .96 arasında; 4960 aylık çocuklarda .88 ile .95 arasında ve 61-72 aylık çocuklarda ise .87 ile.96 arasındadır (Özbey, 2019).

\section{Program ve Uygulama Süreci}

Psikolojik Sağlamlık Programı hazırlama sürecinde ilk olarak psikolojik sağlamlık konusu ile ilgili yurt içi ve yurtdışı literatür taraması yapılmış ve edinilen bilgiler ışı̆̆ında programın alt temaları oluşturulmuştur. Bu alt temalara yönelik MEB Okul Öncesi Eğitim Programı'ndaki kazanım göstergeler incelenerek Psikolojik Sağlamlık Programı'nın kazanım göstergeleri belirlenmiştir. Belirlenen alt temalar ve kazanım göstergeler ile ilgili olarak okul öncesi eğitimi alanında program ve sosyal-duygusal gelişim alanında çalışan 5 akademisyenden uzman görüşü alınmıştır. Alt temalar ve kazanım göstergeler temel alınarak oyun, sanat, drama vb. etkinlik türleri hazırlanmıştır. Programın geliştirme sürecinde 1 klinik psikolog, 2 psikolojik danışman, 1 çocuk gelişimi öğretmeni ve 1 okul öncesi öğretmenin görüşleri de dikkate alınarak etkinlikler hazırlanmıştır. Hazırlanan programa, okul öncesi eğitimi alanında program ve sosyal-duygusal gelişim çalışan 5 akademisyenden uzman görüşleri alınarak son hali verilmiştir. Araştırmada uygulanan "Psikolojik Sağlamlık Programı" bütünleştirilmiş 30 etkinlikten oluşmaktadır. Psikolojik Sağlamlık Programı, iletişim kurma/sosyal performans, öz-kontrol düşüncelilik, atılganlık, duygusal istikrar/stresle başa çıkma, görev yönelimi, keşfetmekten hoşlanma olmak üzere 6 alt temadan oluşmaktadır. Programda; olumlu iletişim kurma, kendini ifade etme, arkadaşlık kurabilme, kendini kontrol edebilme, kurallara uyma, saygılı olma, nezaket, empati, düşünceli olma, girişkenlik, özgüven, problem çözme, duyguları fark etme ve tanıma, olumsuz bir durum sonrası kendini toparlama, stresle başa çıma/öfke kontrolü, göreve yönelme, verilen görevi yerine getirme, dikkatini yoğunlaştırma, sorumluluk alma, yenilikten ve keşfetmekten hoşlanma, merak etme, soru sorma, iyimser olma, cesaret ve sabırlı olma gibi beceriler kazandırmaya yönelik etkinlikler yer almaktadır.

Program hazırlanırken eş zamanlı olarak, programda kullanılacak Türk müziği eserlerini seçme aşaması gerçekleştirilmiştir. Klasik müziğe kendi kültürümüzden bir alternatif olarak, çocukların tüm gelişim alanlarına katkı sağlayacağı ve psikolojik sağlamlığı destekleyeceği düşünülerek programda Türk müziğine yer verilmiştir. Türk müziği alanında üniversitelerin Türk müziği anabilim dallarında görev yapan öğretim üyelerinin önerileri ile birçok eser araştırmacılar tarafından dinlenilmiş ve 68 Türk müziği eseri seçilmiştir. Üç okul öncesi öğretmeni ve araştırmacılar bu eserleri dinlemiş ve görüşleri sonucu eser sayısı 36 olarak belirlenmiştir. Son aşamada ise Türk müziği alanında beş akademisyen ve Okul öncesi eğitimi alanında iki akademisyenin görüşleri doğrultusunda 32 Türk müziği eseri uygun bulunmuştur. Psikolojik Sağlamlık Programı iki deney grubuna da uygulanmıştır, 1. deney grubunda sınıf öğretmeni uygularken, 2. deney grubunda Psikolojik Sağlamlık Programı Türk müziği eserleri de entegre edilerek araştırmacı tarafından uygulanmıştır. Programın uygulama sürecinde ilk aşamada, araştırmacı tarafından programı uygulayan deney grubu öğretmeniyle günlük görüşmeler yapılmış, materyaller öğretmene verilmiş, nasıl uygulayacağı anlatılmış, uygulama sonrası da değerlendirmesi alınmıştır. Araştırmacı uygulamaya diğer deney grubundan 1 gün önce başlamış olup, sınıfta yaptı̆̆ uygulamaları deney grubu öğretmeniyle 
resim, video görselleri paylaşarak uygulamada birlik sağlanmıştır. Kontrol grubunda ise sadece Milli Eğitim Bakanlığı Müfredatı uygulanmış başka bir uygulama yapılmamıştır. Türk Müziği Destekli Psikolojik Sağlamlık Programı haftada 5 gün ve 4 hafta süreyle uygulanmıştır. Türk müziği eserleri, güne başlama, merkezler, toplanma-temizlik, sanat etkinliği, drama/dans, oyun etkinliği, dinlenme ve eve gidiş olmak üzere 8 kategoride gruplanmış ve gün içinde Psikolojik Sağlamlık Programıyla birlikte etkinlik geçişlerine göre günlük ortalama 30 dk eserler sözsüz olarak dinlenilmiştir. Türk müziği eserleri içerisinde örneğin; dinlenme kategorisinde Mâhûr Saz Semâ̂̂-Refik Talat Alpman, oyun etkinliğinde Hicaz Mandıra, dansdrama kategorisinde ise Üsküdar'a Gider İken gibi eserlere yer verilmiştir.

\section{Sinırlılıklar}

1. Program uygulaması 10 hafta, haftada 3 gün olarak planlanmışken, pandemi süreci nedeniyle 4 hafta haftanın 5 günü uygulanmıştır. Uzaktan eğitime geçilmesi nedeniyle 22 etkinlik uygulanabilmiştir.

2. Gönüllü ve puanları birbirine yakın olan farklı gruplar seçilmeye çalışılmıştır. 2 müzikli deney, 1 müziksiz deney ve 1 kontrol grubu olarak 4 grupla sürece başlanılmış olup, müzikli diğer deney grubu öğretmeninin Covid olması nedeniyle grup iptal edilerek 3 grupla devam edilmiştir.

3. Pandemi nedeniyle çocuk sayılarının ve cinsiyetlerinin eşitlenmesi mümkün olamamiştır.

4. Okulların kapanarak uzaktan eğitime geçilmesi nedeniyle kalıcılık testi uygulanamamıştır.

5. Türk müziği eserleri olarak “Mâhûr Saz Semâî, Hicaz Mandıra, Üsküdar'a Gider İken" gibi eserlerin yer aldığ 32 eser seçilmiştir.

\section{Verilerin Analizi}

Araştırmanın nicel boyutunda, parametrik olmayan testlerden Kruskal Wallis H Testi, Mann Whitney U Testi ve Wilcoxon İşaretli Sıralar Testi ile analiz edilerek karşılaştırmalar yapılmıştır.

Araştırmanın nitel boyutunda ise Öğretmen Görüşme Formu'na öğretmenlerin verdikleri cevaplar incelenerek betimsel analiz yapılmıştır.

\section{BULGULAR}

$\mathrm{Bu}$ bölümde, araştırma kapsamında geliştirilen Psikolojik Sağlamlık Programı́nın deney grupları ve kontrol grubundaki çocukların psikolojik sağlamlık düzeyleri üzerindeki etkisine ilişkin analiz sonuçlarına yer verilmiştir.

\section{Deney ve Kontrol Grupları Ön Test}

Tablo 1'de ve Grafik 1'de deney ve kontrol gruplarının Psikolojik Sağlamlık Ölçeği'ne ilişkin ön test puanlarına ilişkin analizlere yer verilmiştir. 
Tablo 1. Deney ve Kontrol Gruplarının Ön Test Puanlarına İlişkin Kruskal Wallis H Testi

\begin{tabular}{|c|c|c|c|c|c|c|c|c|}
\hline \multirow{19}{*}{ 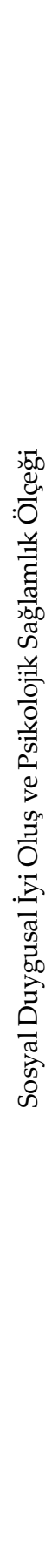 } & & Grup & $\mathrm{N}$ & $\begin{array}{l}\text { Sira } \\
\text { Ort. }\end{array}$ & Sd & $\mathrm{X}^{2}$ & $\mathrm{P}$ & $\begin{array}{c}\text { Farkın kaynağı Mann } \\
\text { Whitney } \\
\text { U testi }\end{array}$ \\
\hline & \multirow{3}{*}{$\begin{array}{l}\text { İletişim Kurma/ } \\
\text { Sosyal Performas }\end{array}$} & Müzikli Deney Grubu & 5 & 5.50 & \multirow{3}{*}{2} & \multirow{3}{*}{5.34} & \multirow{3}{*}{0.07} & \\
\hline & & Müziksiz Deney Grubu & 9 & 13.06 & & & & \\
\hline & & Kontrol Grubu & 7 & 12.29 & & & & \\
\hline & \multirow{3}{*}{$\begin{array}{l}\text { Öz kontrol/ } \\
\text { Düşüncelilik }\end{array}$} & Müzikli Deney Grubu & 5 & 6.50 & \multirow{3}{*}{2} & \multirow{3}{*}{3.54} & \multirow{3}{*}{0.17} & \\
\hline & & Müziksiz Deney Grubu & 9 & 12.72 & & & & \\
\hline & & Kontrol Grubu & 7 & 12.00 & & & & \\
\hline & \multirow{3}{*}{ Atılganlık } & Müzikli Deney Grubu & 5 & 8.30 & \multirow{3}{*}{2} & \multirow{3}{*}{3.01} & \multirow{3}{*}{0.22} & \\
\hline & & Müziksiz Deney Grubu & 9 & 10.06 & & & & \\
\hline & & Kontrol Grubu & 7 & 14.14 & & & & \\
\hline & \multirow{3}{*}{$\begin{array}{l}\text { Duygusal İstikrar/ } \\
\text { Stresle Başa Çıkma }\end{array}$} & Müzikli Deney Grubu & 5 & 8.40 & \multirow{3}{*}{2} & \multirow{3}{*}{1.41} & \multirow{3}{*}{0.49} & \\
\hline & & Müziksiz Deney Grubu & 9 & 11.17 & & & & \\
\hline & & Kontrol Grubu & 7 & 12.64 & & & & \\
\hline & \multirow{3}{*}{ Görev Yönelimi } & 1.Müzikli Deney Grubu & 5 & 6.00 & \multirow{3}{*}{2} & \multirow{3}{*}{7.04} & \multirow{3}{*}{$0.03^{*}$} & \multirow{3}{*}{$\begin{array}{l}\text { 1.ort }(20.00)<3 . \text { ort }(26.14) \\
\mathrm{p}<0.00^{* *}\end{array}$} \\
\hline & & $\begin{array}{l}\text { 2.Müziksiz Deney } \\
\text { Grubu }\end{array}$ & 9 & 10.33 & & & & \\
\hline & & 3.Kontrol Grubu & 7 & 15.43 & & & & \\
\hline & \multirow{3}{*}{$\begin{array}{l}\text { Keşfetmekten } \\
\text { Hoşlanma }\end{array}$} & 1.Müzikli Deney Grubu & 5 & 5.10 & \multirow{3}{*}{2} & \multirow{3}{*}{6.16} & \multirow{3}{*}{$0.04^{*}$} & \multirow{3}{*}{$\begin{array}{l}\text { 1.ort } 20.60<2 \text {.ort } 25.63 \\
\mathrm{p}<0.02^{*}\end{array}$} \\
\hline & & $\begin{array}{l}\text { 2.Müziksiz Deney } \\
\text { Grubu }\end{array}$ & 9 & 13.33 & & & & \\
\hline & & 3.Kontrol Grubu & 7 & 12.21 & & & & \\
\hline
\end{tabular}

${ }^{* *} \mathrm{p}<0.01,{ }^{*} \mathrm{p}<0.05$

Tablo 1 incelendiğinde; araştırmaya katılan grupların Psikolojik Sağlamlık Ölçeği'nin İletişim Kurma/Sosyal Performans $\left(\mathrm{x}^{2}{ }_{(2)}=5.34, \mathrm{p}>0.05\right)$, Öz-kontroll Düşüncelilik $\left(\mathrm{x}^{2}{ }_{(2)}=3.54, \mathrm{p}>0.05\right)$, Atılganlık $\left(\mathrm{x}^{2}{ }_{(2)}=3.01, \mathrm{p}>0.05\right)$ ve Duygusal İstikrar/Stresle Başa Çıkma $\left(\mathrm{x}^{2}{ }_{(2)}=3.01, \mathrm{p}>0.05\right)$ alt ölçeklerinden aldıkları ön test puanları arasında anlamlı farklılık bulunmamaktadır.

Ölçeğin Görev Yönelimi ve Keşfetmekten Hoşlanma alt boyutlarında ise gruplar arasında anlamlı farklılık bulunduğu saptanmıştır. Farkın kaynağını saptamak amacıyla yapılan Mann Whitney 
U Testi sonucunda Görev Yönelimi ( $x^{2}{ }_{(2)}=7.04$, p<0.05) alt ölçeğinde farkın Müzikli Deney Grubu ile Kontrol Grubu arasında Kontrol Grubu lehine olduğu saptanmıştır. Keşfetmekten Hoşlanma $\left(x^{2}{ }_{(2)}=7.04, p<0.05\right)$ alt ölçeğinde ise, farkın Müzikli Deney ile Müziksiz Deney Grubu arasında ve Müziksiz Deney Grubu lehine olduğu saptanmıştır. Grupların ön test puanları grafiği Grafik 1'de verilmiştir.

Grafik 1. Müzikli Deney Grubu, Müziksiz Deney Grubu İle Kontrol Grubu Ön Test Puan Grafiği.

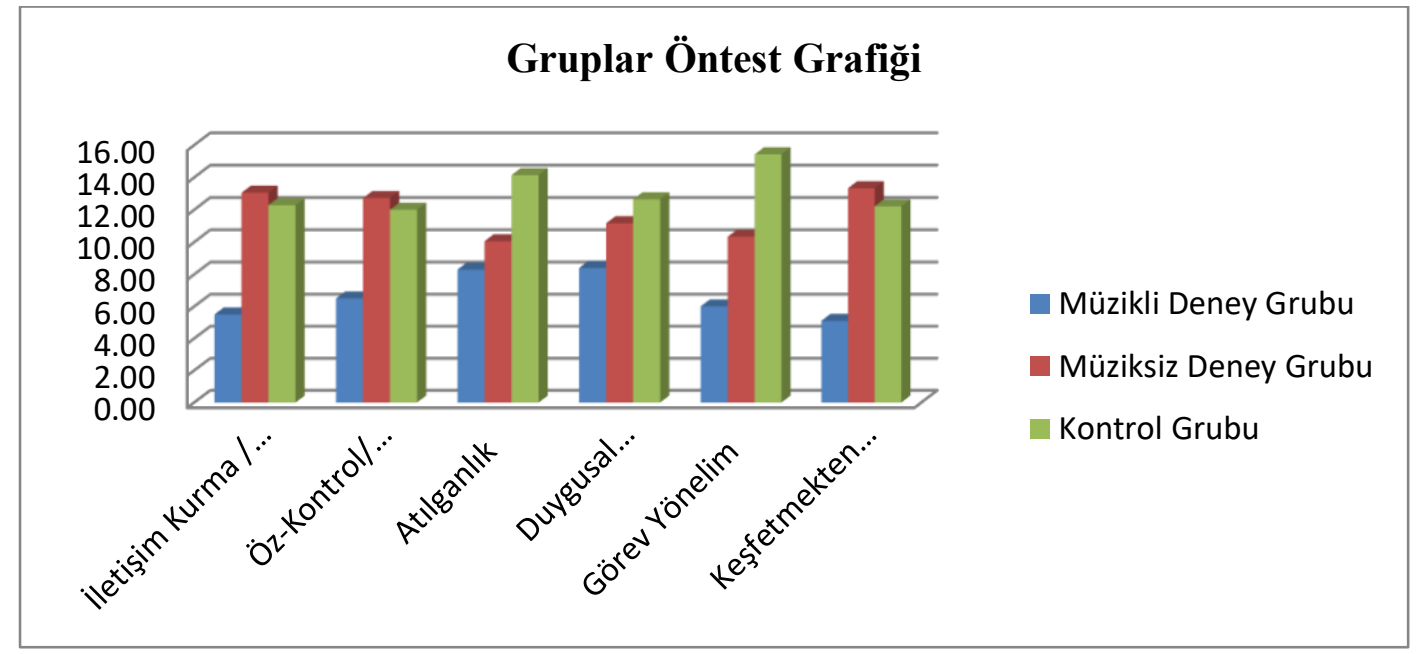

Tablo 1 ve Grafik 1 incelendiğinde Müzikli Deney Grubu'nun puanının “Görev Yönelimi ve Keşfetmekten Hoşlanma" alt boyutlarında her iki gruptan anlamlı oranda düşük olduğunu; diğer alt ölçeklerde de tüm gruplar arasında en düşük puana sahip olduğu görülmektedir.

\section{Müzikli Deney Grubu Ön Test- Son Test}

Tablo 2'de Psikolojik Sağlamlık Ölçeği'ne ilişkin Müzikli Deney Grubu ön test ve son test Wilcoxon İşaretli Sıralar Testi sonuçları verilmiştir.

Tablo 2. Müzikli Deney Grubunun Ön Test ve Son Testlerine İlişkin Wilcoxon İşaretli Stralar Testi

\begin{tabular}{|c|c|c|c|c|c|c|c|c|}
\hline \multirow{9}{*}{ 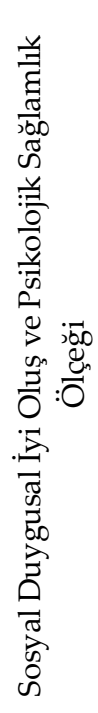 } & Grup & Alt Boyutlar & Ön test-Son test & $\mathrm{n}$ & Sira Ort. & Sira Top. & $\mathrm{Z}$ & $\mathrm{P}$ \\
\hline & \multirow{8}{*}{ 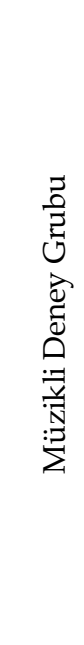 } & \multirow{3}{*}{$\begin{array}{l}\text { İletişim Kurma / Sosyal } \\
\text { Performans }\end{array}$} & Negatif Sira & 0 & 0.00 & 0,00 & \multirow{3}{*}{-2.02} & \multirow{3}{*}{$0.04^{*}$} \\
\hline & & & Pozitif Sira & 5 & 3.00 & 15.00 & & \\
\hline & & & Eşit & 0 & & & & \\
\hline & & \multirow{3}{*}{ Öz-Kontrol/ Düşüncelilik } & Negatif Sıra & 0 & 0.00 & 0.00 & \multirow{3}{*}{-2.02} & \multirow{3}{*}{$0.04^{\prime}$} \\
\hline & & & Pozitif Sıra & 5 & 3.00 & 15.00 & & \\
\hline & & & Eşit & 0 & & & & \\
\hline & & \multirow{2}{*}{ Atılganlık } & Negatif Sira & 0 & 0.00 & 0.00 & \multirow{2}{*}{-1.82} & \multirow{2}{*}{0.07} \\
\hline & & & Pozitif Sıra & 4 & 2.50 & 10.00 & & \\
\hline
\end{tabular}




\begin{tabular}{|c|c|c|c|c|c|c|}
\hline & Eşit & 1 & & & & \\
\hline \multirow{3}{*}{$\begin{array}{l}\text { Duygusal İstikrar/Stresle } \\
\text { Başa Çıkma }\end{array}$} & Negatif Sira & 0 & 0.00 & 0.00 & \multirow{3}{*}{-2.02} & \multirow{3}{*}{$0.04^{*}$} \\
\hline & Pozitif Sira & 5 & 3.00 & 15.00 & & \\
\hline & Eşit & 0 & & & & \\
\hline \multirow{3}{*}{ Görev Yönelimi } & Negatif Sira & 0 & 0.00 & 0.00 & \multirow{3}{*}{-2.03} & \multirow{3}{*}{$0.04^{*}$} \\
\hline & Pozitif Sıra & 5 & 3.00 & 15.00 & & \\
\hline & Eşit & 0 & & & & \\
\hline \multirow{3}{*}{ Keşfetmekten Hoşlanma } & Negatif Sira & 0 & 0.00 & 0.00 & \multirow{3}{*}{-2.04} & \multirow{3}{*}{$0.04^{*}$} \\
\hline & Pozitif Sıra & 5 & 3.00 & 15.00 & & \\
\hline & Eşit & 0 & & & & \\
\hline
\end{tabular}

${ }^{* *} \mathrm{p}<0.01,{ }^{*} \mathrm{p}<0.05$

Tablo 2 incelendiğinde, Müzikli Deney Grubu'ndaki çocukların Psikolojik Sağlamlık Ölçeği' nden aldıkları ön-son test puanları arasındaki farkın; İletişim Kurma / Sosyal Performans ( $\mathrm{z}=$ 2.02, p<0.05), Öz-Kontrol/ Düşüncelilik ( $\mathrm{z}=-2.02, \mathrm{p}<0.05)$, Duygusal İstikrar/Stresle Başa Çıkma ( $\mathrm{z}=$ 2.02, $\mathrm{p}<0.05)$, Görev Yönelimi ( $\mathrm{z}=-1.82, \mathrm{p}<0.05)$, Keşfetmekten Hoşlanma $(\mathrm{z}=-2.02, \mathrm{p}<0.05)$ alt boyutlarında istatistiksel olarak anlamlı olduğu, Atılganlık $(\mathrm{z}=-1.82, \mathrm{p}>0.05)$ alt boyutunda ise anlamlı fark olmadığı görülmektedir. Fark puanlarının sıra toplamları dikkate alındığında farkın pozitif sıralar yani son testler lehine olduğu ve Müzikli Deney Grubu'nun program uygulandıktan sonra puanlarını artırdığı görülmektedir.

\section{Müziksiz Deney Grubu Ön Test- Son Test}

Tablo 3'te Psikolojik Sağlamlık Ölçeği'ne ilişkin Müziksiz Deney Grubu ön test ve son test Wilcoxon İşaretli Sıralar Testi sonuçları verilmiştir.

Tablo 3. Müziksiz Deney Grubunun Ön Test ve Son Testlerine İlişkin Wilcoxon Işaretli Stralar Testi

\begin{tabular}{|c|c|c|c|c|c|c|c|c|}
\hline \multirow{6}{*}{ 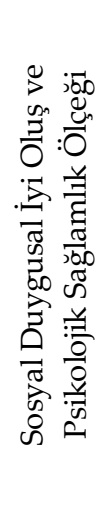 } & Grup & Alt Boyutlar & Öntest-Sontest & $\mathrm{N}$ & $\begin{array}{l}\text { Sira } \\
\text { Ort. }\end{array}$ & $\begin{array}{l}\text { Sira } \\
\text { Top. }\end{array}$ & Z & $\mathrm{P}$ \\
\hline & \multirow{5}{*}{ 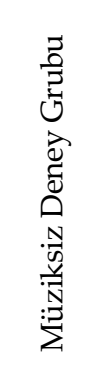 } & \multirow{3}{*}{$\begin{array}{l}\text { İletişim Kurma / } \\
\text { Sosyal Performans }\end{array}$} & Negatif Sira & 0 & 0.00 & 0.00 & \multirow{3}{*}{-2.02} & \multirow{3}{*}{$0.04^{*}$} \\
\hline & & & Pozitif Sıra & 5 & 3.00 & 15.00 & & \\
\hline & & & Eşit & 4 & & & & \\
\hline & & \multirow{2}{*}{$\begin{array}{l}\text { Öz-Kontrol/ } \\
\text { Düşüncelilik }\end{array}$} & Negatif Sıra & 0 & 0.00 & 0.00 & \multirow{2}{*}{-2.03} & \multirow{2}{*}{$0.04^{*}$} \\
\hline & & & Pozitif Sira & 5 & 3.00 & 15.00 & & \\
\hline
\end{tabular}




\begin{tabular}{|c|c|c|c|c|c|c|}
\hline & Eşit & 4 & & & & \\
\hline \multirow{3}{*}{ Atılganlık } & Negatif Sira & 0 & 0.00 & 0.00 & \multirow{3}{*}{-2.26} & \multirow{3}{*}{$0.02^{*}$} \\
\hline & Pozitif Sira & 6 & 3.50 & 21.00 & & \\
\hline & Eşit & 3 & & & & \\
\hline \multirow{3}{*}{$\begin{array}{l}\text { Duygusal } \\
\text { İstikrar/Stresle } \\
\text { Başa Çıkma }\end{array}$} & Negatif Sira & 1 & 1.00 & 1.00 & \multirow{3}{*}{-2.55} & \multirow{3}{*}{$0.01^{* *}$} \\
\hline & Pozitif Sira & 8 & 5.50 & 44.00 & & \\
\hline & Eşit & 0 & & & & \\
\hline \multirow{3}{*}{ Görev Yönelimi } & Negatif Sira & 0 & 0.00 & 0.00 & \multirow{3}{*}{-2.54} & \multirow{3}{*}{$0.01^{* *}$} \\
\hline & Pozitif Sira & 8 & 4.50 & 36.00 & & \\
\hline & Eşit & 1 & & & & \\
\hline \multirow{3}{*}{$\begin{array}{l}\text { Keşfetmekten } \\
\text { Hoşlanma }\end{array}$} & Negatif Sira & 1 & 1.00 & 1.00 & \multirow{3}{*}{-2.01} & \multirow{3}{*}{$0.04^{*}$} \\
\hline & Pozitif Sıra & 5 & 4.00 & 20.00 & & \\
\hline & Eşit & 3 & & & & \\
\hline
\end{tabular}

${ }^{* *} \mathrm{p}<0,01,{ }^{*} \mathrm{p}<0,05$

Tablo 3 incelendiğinde, Müziksiz Deney Grubu'ndaki çocukların Psikolojik Sağlamlık Ölçeği' nden aldıkları ön-son test puanları arasındaki farkın; İletişim Kurma / Sosyal Performans ( $\mathrm{z}=$ 2.02, $\mathrm{p}<0.05), \ddot{O} z$-Kontrol/ Düşüncelilik $(\mathrm{z}=-2.03, \mathrm{p}<0.05)$, Atılganlik $(\mathrm{z}=-2.26, \mathrm{p}<0.05)$, Duygusal İstikrar/Stresle Başa Çıkma ( $\mathrm{z}=-2.55, \mathrm{p}<0.05)$, Görev Yönelimi $(\mathrm{z}=-2.54, \mathrm{p}<0.05)$, Keşfetmekten Hoşlanma ( $\mathrm{z}=-2.01, \mathrm{p}<0.05)$ alt boyutlarında istatistiksel olarak anlamlı olduğu görülmektedir. Fark puanlarının sıra toplamları dikkate alındığında farkın pozitif sıralar yani son testler lehine olduğu, Müziksiz Deney Grubu'nun program uygulandıktan sonra puanlarını artırdığı görülmektedir.

\section{Kontrol Grubu Ön Test- Son Test}

Tablo 4'te Psikolojik Sağlamlık Ölçeği'ne ilişkin Kontrol Grubu ön test ve son test Wilcoxon İşaretli Sıralar Testi sonuçları verilmiştir.

Tablo 4. Kontrol Grubunun Ön Test Ve Son Testlerine İlişkin Wilcoxon İşaretli Stralar Testi

\begin{tabular}{|c|c|c|c|c|c|c|c|c|}
\hline 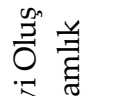 & Grup & Alt Boyutlar & Öntest-Sontest & $\mathrm{N}$ & $\begin{array}{l}\text { Sira } \\
\text { Ort. }\end{array}$ & $\begin{array}{l}\text { Sira } \\
\text { Top. }\end{array}$ & Z & $\mathrm{P}$ \\
\hline $\begin{array}{l}\widetilde{W} \\
0\end{array}$ & ప & \multirow{3}{*}{$\begin{array}{l}\text { İletişim Kurma } \\
\text { Sosyal Performans }\end{array}$} & Negatif Sıra & 5 & 3.60 & 18.00 & \multirow{3}{*}{-1.57} & \multirow{3}{*}{0.12} \\
\hline $\begin{array}{l}\overrightarrow{0} \\
\vec{\sigma}\end{array}$ & 苞 & & Pozitif Sira & 1 & 3.00 & 3.00 & & \\
\hline $\begin{array}{l}n \\
0 \\
0\end{array}$ & 婇 & & Eşit & 1 & & & & \\
\hline
\end{tabular}




\begin{tabular}{|c|c|c|c|c|c|c|}
\hline \multirow{3}{*}{$\begin{array}{l}\text { Öz-Kontrol/ } \\
\text { Düşüncelilik }\end{array}$} & Negatif Sira & 7 & 4.00 & 28.00 & \multirow{3}{*}{-2.38} & \multirow{3}{*}{$0.02^{*}$} \\
\hline & Pozitif Sira & 0 & 0.00 & 0.00 & & \\
\hline & Eşit & 0 & & & & \\
\hline \multirow{3}{*}{ Atılganlik } & Negatif Sira & 7 & 4.00 & 28.00 & \multirow{3}{*}{-2.37} & \multirow{3}{*}{$0.02^{*}$} \\
\hline & Pozitif Sira & 0 & 0.00 & 0.00 & & \\
\hline & Eşit & 0 & & & & \\
\hline \multirow{3}{*}{$\begin{array}{l}\text { Duygusal } \\
\text { İstikrar/Stresle } \\
\text { Başa Çıkma }\end{array}$} & Negatif Sira & 6 & 3.50 & 21.00 & \multirow{3}{*}{-2.23} & \multirow{3}{*}{$0.03^{*}$} \\
\hline & Pozitif Sıra & 0 & 0.00 & 0.00 & & \\
\hline & Eşit & 1 & & & & \\
\hline \multirow{3}{*}{ Görev Yönelimi } & Negatif Sira & 6 & 4.33 & 26.00 & \multirow{3}{*}{-2.04} & \multirow{3}{*}{$0.04^{*}$} \\
\hline & Pozitif Sira & 1 & 2.00 & 2.00 & & \\
\hline & Eşit & 0 & & & & \\
\hline \multirow{3}{*}{$\begin{array}{l}\text { Keşfetmekten } \\
\text { Hoşlanma }\end{array}$} & Negatif Sira & 7 & 4,00 & 28,00 & \multirow{3}{*}{-2.37} & \multirow{3}{*}{$0.02^{*}$} \\
\hline & Pozitif Sıra & 0 & 0,00 & 0,00 & & \\
\hline & Eşit & 0 & & & & \\
\hline
\end{tabular}

${ }^{* *} \mathrm{p}<0,01,{ }^{*} \mathrm{p}<0,05$

Tablo 4 incelendiğinde, Kontrol Grubu'ndaki çocukların Psikolojik Sağlamlık Ölçeği'nden aldıkları ön-son test puanları arasındaki farkın; İletişim Kurma / Sosyal Performans ( $\mathrm{z}=-1.57$, p>0.05) alt boyutunda istatiksel olarak anlamlı olmadığı, Öz-Kontrol/ Düşüncelilik ( $\mathrm{z}=-2.38$, $\mathrm{p}<0.05)$, Atılganlık $(\mathrm{z}=-2.37, \mathrm{p}<0.05)$, Duygusal İstikrar/Stresle Başa Çıkma $(\mathrm{z}=-2.23, \mathrm{p}<0.05)$, Görev Yönelimi $(\mathrm{z}=-2.04, \mathrm{p}<0.05)$, Keşfetmekten Hoşlanma $(\mathrm{z}=-2.37, \mathrm{p}<0.05)$ alt boyutlarında istatistiksel olarak anlamlı olduğu görülmektedir. Fark puanlarının sıra toplamları dikkate alındığında farkın negatif sıralar yani ön testler lehine olduğu görülmektedir. Başka bir ifadeyle kontrol grubunun son test puanlarının ön test puanlarına göre anlamlı şekilde puanlarının düştüğü görülmektedir.

\section{Deney Grupları ve Kontrol Grubu Son Testlerin Karşılaştırması}

Tablo 5'te ve Grafik 2'de deney ve kontrol gruplarının Psikolojik Sağlamlık Ölçeği'nin son test karşılaştırmalarına ilişkin analizlere yer verilmiştir. 
Tablo 5. Deney ve Kontrol Gruplarının Son Test Puanlarına Illişkin Kruskal Wallis H Testi

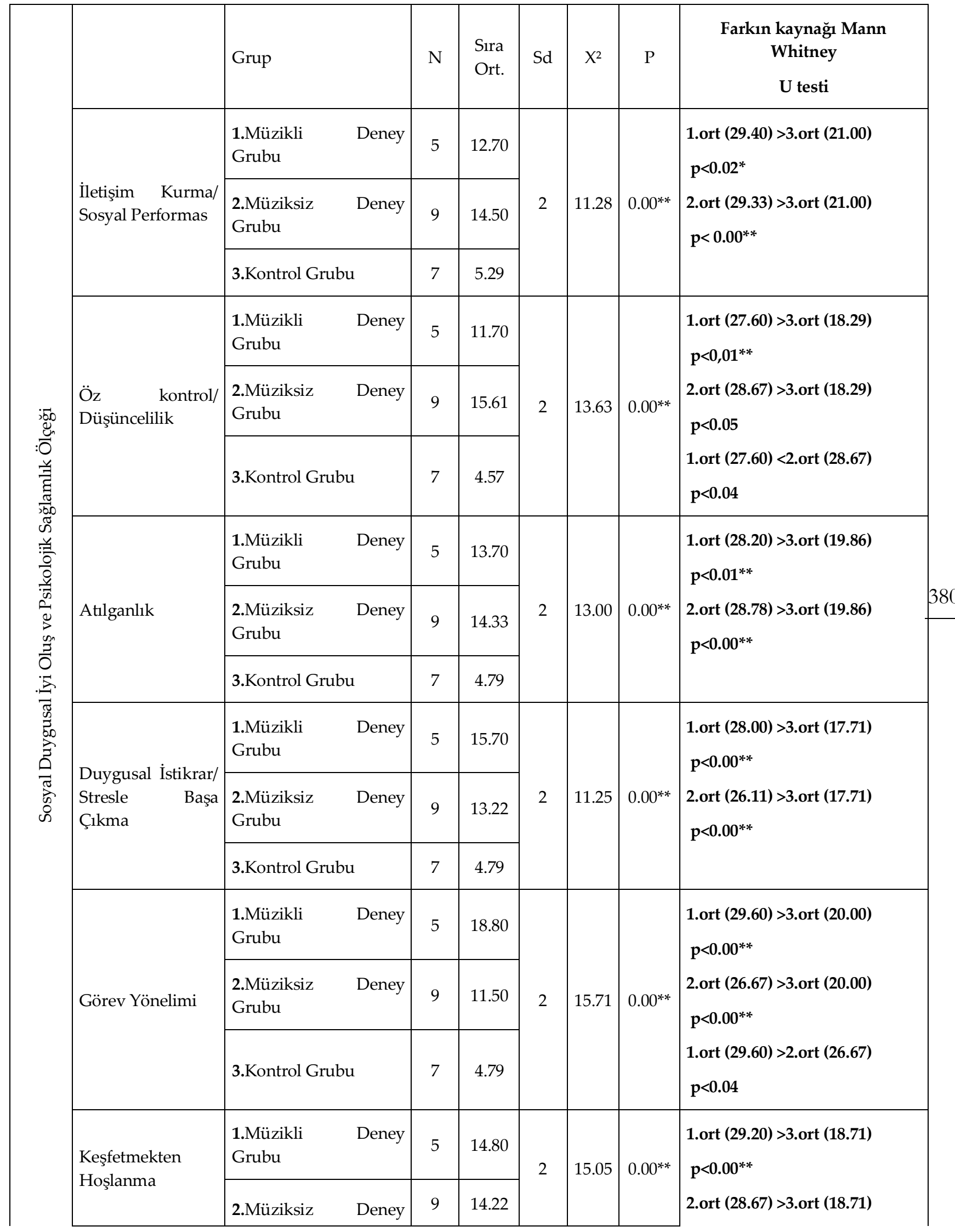




\begin{tabular}{|l|l|l|l|l|l|} 
Grubu & & & \multirow{4}{*}{} & & $\mathbf{p}<0.00^{* *}$ \\
\cline { 1 - 4 } & 3.Kontrol Grubu & 7 & 4.14 & & \\
\hline
\end{tabular}

${ }^{* *} \mathrm{p}<0.01,{ }^{*} \mathrm{p}<0.05$

Tablo 5 incelendiğinde; araştırmaya katılan grupların son test Psikolojik Sağlamlık Ölçeği'nin İletişim Kurma/Sosyal Performans ( $\left.\mathrm{x}^{2}{ }_{(2)}=11.28, \mathrm{p}<0.05\right)$, Öz-kontrol/Düşüncelilik $\left(\mathrm{x}^{2}{ }_{(2)}=13.63, \mathrm{p}<0.05\right)$, Atılganlık $\left(\mathrm{x}^{2}{ }_{(2)}=13.00, \mathrm{p}<0.05\right)$, Duygusal İstikrar/Stresle Başa Çıkma $\left(\mathrm{x}^{2}{ }_{(2)}=11.25, \mathrm{p}<0.05\right)$, Görev Yönelimi $\left(\mathrm{x}^{2}{ }_{(2)}=15.71, \mathrm{p}<0.05\right)$, Keşfetmekten Hoşlanma $\left(\mathrm{x}^{2}{ }_{(2)}=15.05, \mathrm{p}<0.05\right)$ alt boyutlarının sira ortalamaları arasında anlamlı farklılık olduğu görülmektedir.

Ölçeğin tüm alt boyutlarında gruplar arasında anlamlı farklılık bulunduğu saptanmıştır. Farkın kaynağını saptamak amacıyla yapılan Mann Whitney U Testi sonucunda;

Müzikli Deney ve Kontrol Gruplarının son testlerinde İletişim Kurma / Sosyal Performans (U=3,50, p<0.05), Öz-Kontrol/ Düşüncelilik ( $\mathrm{U}=0,50, \mathrm{p}<0.05)$, Attlganlık $(\mathrm{U}=2,50, \mathrm{p}<0.05)$, Duygusal İstikrar/Stresle Başa Çıkma ( $\mathrm{U}=0,00, \mathrm{p}<0.05)$, Görev Yönelimi $(\mathrm{U}=0,00, \mathrm{p}<0.05)$, Keşfetmekten Hoşlanma $(\mathrm{U}=0,00, \mathrm{p}<0.05)$ alt boyutlarından aldıkları puanlar arasında Müzikli Deney Grubu lehine anlamlı farklılık gösterdiği saptanmıştır.

Müziksiz Deney ve Kontrol Gruplarının son testlerinde İletişim Kurma / Sosyal Performans ( $\mathrm{U}=5,50, \mathrm{p}<0.05)$, Öz-Kontrol/ Düşüncelilik $(\mathrm{U}=3,50, \mathrm{p}<0.05)$, Atılganlık $(\mathrm{U}=3,00, \mathrm{p}<0.05)$, Duygusal İstikrar/Stresle Başa Çıkma (U=5,50, $\mathrm{p}<0.05)$, Görev Yönelimi $(\mathrm{U}=5,50, \mathrm{p}<0.05)$, Keşfetmekten Hoşlanma $(\mathrm{U}=1,00, \mathrm{p}<0.05)$ alt boyutlarından aldıkları puanlar arasında Müziksiz Deney Grubu'nun lehine anlamlı farklılık bulunduğu saptanmıştır.

Müzikli ve Müziksiz Deney Gruplarının son testlerinde İletişim Kurma / Sosyal Performans $(\mathrm{U}=17,00, \mathrm{p}>0.05)$, Atılganlık ( $\mathrm{U}=21,00, \mathrm{p}>0.05)$, Duygusal İstikrar/Stresle Başa Çıkma $(\mathrm{U}=16,00$, $\mathrm{p}>0.05)$, Keşfetmekten Hoşlanma $(\mathrm{U}=21,00, \mathrm{p}>0.05)$ alt boyutlarından aldıkları puanlar arasında anlamlı farklılık olmadı̆̆1 saptanmıştır. Öz-Kontrol/Düşüncelilik (U=9,00, p<0.05), Görev Yönelimi $(\mathrm{U}=1,00, \mathrm{p}<0.05)$ alt boyutlarından aldıkları puanlar arasında ise anlamlı farklılık olduğu görülmektedir. Grupların son test puanları grafiği Grafik 2' de verilmiştir.

Grafik 2. Deney ve Kontrol Grupları Son Test Puan Grafiği

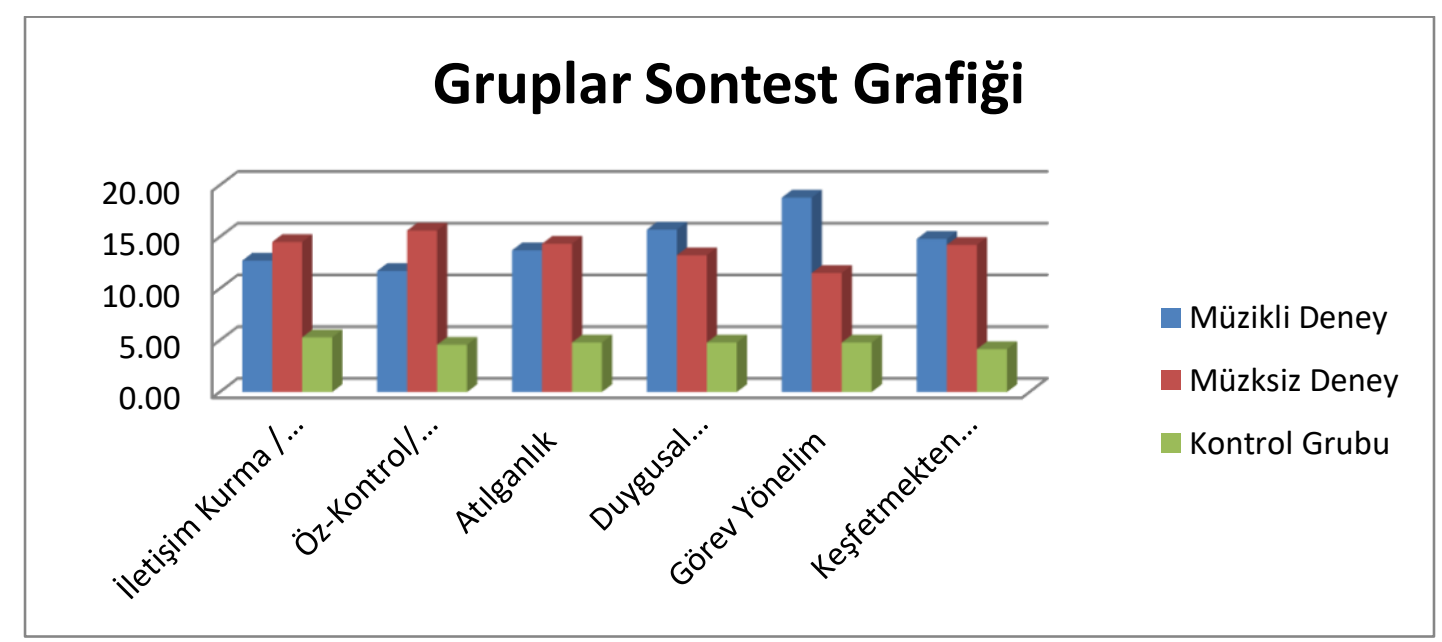


Grafik 2 incelendiğinde, Müzikli Deney Grubu'nun program uygulandıktan sonra puan sira ortalamasını tüm alt boyutlarda artırdığı, Görev Yönelimi alt boyutunda ise Müziksiz Deney Grubu'na fark yaratarak öne geçtiği görülmektedir.

Öz-kontrol/Düşüncelilik alt boyutunda ise, Müziksiz Deney Grubu'nun sıra ortalamasının Müzikli Deney Grubu'nun sıra ortalamasından yüksek olduğu görülmektedir, ancak Müzikli Deney Grubu'nun program öncesi düşük puanla başlayıp (Tablo 1 ve Grafik 1) aradaki farkı azaltarak Müziksiz Deney Grubu'na az farkla yetişmesi dikkati çekmektedir. Ortalamalar arasındaki farkın hangi gruplar arasında olduğunu belirlemek için yapılan Mann Whitney U testlerinde verilmiştir.

Müzikli ve Müziksiz Deney Gruplarının Psikolojik Sağlamlık Ölçeği'nden aldıkları son test puanları incelendiğinde iki grubun program sonrasında tüm alt boyutlarda puanlarını artırdığını söyleyebilmek mümkündür. Öz-Kontrol/Düşüncelilik, alt boyutunda Müziksiz Deney Grubu'nun aldığ1 puanın yüksek olduğu ancak Müzikli Deney Grubu'nun düşük puanla başlayıp puanını artırarak aradaki farkı azalttığı, Görev Yönelimi alt boyutunda ise Müzikli Deney Grubu'nun aldığı puanın Müziksiz Deney Grubu'nun puanından yüksek olduğunu söyleyebilmek mümkündür. Keşfetmek Hoşlanma alt boyutunda ön testte çıkan anlamlı farkın, Müzikli Deney Grubu'nun puanlarını artırmasıyla son testte bu farkı ortadan kaldırdığını söylemek mümkündür.

\section{Deney Grupları ve Kontrol Grubu Betimsel İstatistikler}

Psikolojik Sağlamlık Ölçeği ön-son test puanlarına ilişkin betimsel istatistik sonuçları Tablo 6 'da verilmiştir.

Tablo 6. Müzikli Deney, Müziksiz Deney ve Kontrol Grubunun Ön Test ve Son Test Dĕ̆gerlerine İlişkin Betimsel İstatistikleri

\begin{tabular}{|c|c|c|c|c|c|c|}
\hline \multirow{2}{*}{ Alt Ölçek } & \multirow{2}{*}{ Grup } & \multirow{2}{*}{$\mathrm{N}$} & \multicolumn{2}{|c|}{ ÖN TEST } & \multicolumn{2}{|c|}{ SON TEST } \\
\hline & & & $x$ & Ss & $x$ & Ss \\
\hline \multirow{3}{*}{$\begin{array}{l}\text { İletişim Kurma / Sosyal } \\
\text { Performans }\end{array}$} & Müzikli Deney & 5 & 21,00 & 3,16 & 29,40 & 0,89 \\
\hline & Müziksiz Deney & 9 & 25,44 & 5,36 & 29,33 & 2,00 \\
\hline & Kontrol & 7 & 24,86 & 0,69 & 21,00 & 5,45 \\
\hline \multirow{3}{*}{ Öz-Kontrol/ Düşüncelilik } & Müzikli Deney & 5 & 20,60 & 4,98 & 27,60 & 2,30 \\
\hline & Müziksiz Deney & 9 & 25,11 & 4,94 & 28,67 & 4,00 \\
\hline & Kontrol & 7 & 24,86 & 2,34 & 18,29 & 4,68 \\
\hline \multirow{3}{*}{ Atılganlık } & Müzikli Deney & 5 & 21,60 & 6,07 & 28,20 & 4,02 \\
\hline & Müziksiz Deney & 9 & 23,33 & 4,72 & 28,78 & 3,67 \\
\hline & Kontrol & 7 & 26,00 & 2,58 & 19,86 & 3,80 \\
\hline \multirow{3}{*}{$\begin{array}{l}\text { Duygusal İstikrar/Stresle } \\
\text { Başa Çıkma }\end{array}$} & Müzikli Deney & 5 & 19,60 & 3,85 & 28,00 & 2,35 \\
\hline & Müziksiz Deney & 9 & 20,33 & 2,78 & 26,11 & 4,08 \\
\hline & Kontrol & 7 & 20,57 & 1,51 & 17,71 & 2,21 \\
\hline \multirow{3}{*}{ Görev Yönelimi } & Müzikli Deney & 5 & 20,00 & 2,12 & 29,60 & 0,89 \\
\hline & Müziksiz Deney & 9 & 22,56 & 4,16 & 26,67 & 1,80 \\
\hline & Kontrol & 7 & 26,14 & 1,57 & 20,00 & 4,62 \\
\hline \multirow{3}{*}{ Keşfetmekten Hoşlanma } & Müzikli Deney & 5 & 20,60 & 2,79 & 29,20 & 1,79 \\
\hline & Müziksiz Deney & 9 & 25,33 & 3,43 & 28,67 & 2,65 \\
\hline & Kontrol & 7 & 24,43 & 2,51 & 18,71 & 3,86 \\
\hline
\end{tabular}


Tablo 6'ya göre her iki deney grubu Kontrol Grubu'na göre son testlerde ilerleme kaydetmiştir. Bununla birlikte deney gruplarının ön-son test ortalamalarındaki artış oranı, araştırmanın temel amacını oluşturan müzik destekli eğitim programının etkisini ortaya koymak açısından önemli görülmektedir. Müzikli Deney Grubu'nun ön testlere göre son testlerindeki puan artışının Müziksiz Deney Grubu'na göre daha fazla olduğu dikkati çekmektedir. Örneğin ölçeğin İletişim Kurma/Sosyal Performans alt boyutunda Müzikli Deney Grubu ortalaması x=20 iken son test puan ortalaması 29.40'a yükselmiştir. Aynı alt boyutta Müziksiz Deney Grubu'nun ön test puan ortalaması $X=25.44$ iken son test ortalaması $X=29.33$ 'dür. Diğer tüm boyutlarda Müzikli Deney Grubu'nun Müziksiz Deney Grubu'na göre daha yüksek oranda puan artışı gerçekleştirdiği görülmektedir.

\section{Araştırmanın Nitel Bulguları}

Deney grupları öğretmenlerine Psikolojik Sağlamlık Programı'na ilişkin, Müzikli Deney Grubu öğretmenine ek olarak Türk Müziği'ne ilişkin, Kontrol Grubu öğretmenine ise son testte çocukların puanının düşme sebebine yönelik sorular uzman görüşleri doğrultusunda hazırlanmıştır. Öğretmenlerin sorulara verdikleri cevaplar ses kaydı ile alınarak betimsel analiz yapılmıştır.

Tablo 7. Müzikli ve Müziksiz Deney Grubu Öğretmenlerinin Psikolojik Sağlamlık Programı'na İlişkin Görüşleri

\begin{tabular}{|l|l|}
\hline \multicolumn{2}{|c|}{ Öğretmen Görüşleri } \\
\hline Soru & \multicolumn{2}{|c|}{ Uygulama Sonrası } \\
\hline $\begin{array}{l}\text { 1. Psikolojik Sağlamlık Programı'nın çocukların } \\
\text { gelişimlerine ve sizin mesleki gelişiminize } \\
\text { katkılarını nasıl değerlendirirsiniz? }\end{array}$ & $\begin{array}{l}\text { 1. Çocukların gelişim alanları (sosyal beceriler, muhakeme, } \\
\text { duygu düzenleme vb., yeni kelimeler/kavramlar öğrenme, } \\
\text { bilginin davranışa dönüşmesi.) } \\
\text { 2. Öğretmenin mesleki gelişimi (program becerisi, psikolojik } \\
\text { sağlamlığın önemi, müfredata bağlı kalmama) }\end{array}$ \\
\hline
\end{tabular}

Tablo 7 incelendiğinde Psikolojik Sağlamlık Programı, çocuklara sosyal beceriler kazandırma, duygu düzenleme, yeni kavramlar öğrenme, bilginin davranışa dönüşmesi gibi çocuğun sadece sosyal-duygusal gelişimi değil, tüm gelişim alanlarına olumlu katkı sağladığı ifade edilmiştir. Program öğretmenlere ise, etkinlikler içerisinde program becerisi kazanma, psikolojik sağlamlık kavramının önemini fark etme ve müfredata bağlı kalmadan psikolojik sağlamlık gibi programların da uygulanmasının mesleki gelişimine olumlu katkı sağladığ belirtilmiştir.

Müzikli ve Müziksiz Deney Grubu öğretmenleri Psikolojik Sağlamlık Programı'nın çocukların gelişim alanlarına yönelik katkılarını "Çocukların iletişim kurma, arkadaş olma, nezaket gibi sosyal becerilerini geliştirdi. Kurallara uyma, saygılı olma, öz-kontrol, empati, sabırl olma, soru sorma, girişken olma, cesaret, pes etmeme, problem çözme, muhakeme etme, duyguların daha iyi ifade edebilme ve kontrol edebilme, öfke kontrolü, stresle başa çıkma gibi beceriler kazandırarak gelişim alanlarına olumlu katkı să̆ladı. Çocuklarm etkinliklerden sonra öğrendiklerini davranışlarına yansıttı̆̆ını gözlemledim." şeklinde belirtmişlerdir. Mesleki gelişimlerine yönelik görüşlerini ise, "Psikolojik sağlamlığın önemi hakkında eksiklerim varmış, toparlama şansım oldu. Gözümden kaçanlar ve aslında 
eğitimde ilk vermem gerekenleri biraz öteliyormuşum. Öğretmen olarak müfredata bă̆g kalıyoruz. Çocuklara sayğ, kurallara uyma, sabırlı olma, vb. kendi yaptığımız etkinlikler, çocuğa tam olarak bu becerileri kazandırmayabiliyor ancak bu programdaki etkinlikler çok güzel kazandırıyor. Programı uygulamaya başladığımda bu kadar iyi etkili dönütler alacă̆ımı düşünmemiştim." şeklinde ifade etmişlerdir. Müzikli ve Müziksiz Deney grubu öğretmenlerinin Covid 19 sürecinde Psikolojik Sağlamlık Programı'nı uygulaması ve çocukların puanlarının yükselmesinin sebebini programin etkisi olarak belirtmişlerdir.

Tablo 8. Müzikli Deney Grubu Öğretmeninin Türk Müziğine İlişkin Görüşleri

\begin{tabular}{|c|c|}
\hline \multicolumn{2}{|r|}{ Öğretmen Görüşleri } \\
\hline Soru & Uygulama Sonrası \\
\hline $\begin{array}{l}\text { 1. Psikolojik sağlamlık programında } \\
\text { Türk müziği kullanılmasının } \\
\text { çocukların gelişim alanlarına, sınıf } \\
\text { yönetimine ve sizin kişisel/mesleki } \\
\text { performansınıza katkılarını nasıl } \\
\text { değerlendirirsiniz? }\end{array}$ & $\begin{array}{l}\text { 1. Çocukların gelişim alanları (müziğe karşı estetik algı oluşması, dikkati } \\
\text { odaklama, dikkat süresini artırma, mantık ve muhakemede gelişme, } \\
\text { huzurlu ve keyifli çalışma, vb.) } \\
\text { 2. Sınıf yönetimi (çocukların daha sakin olması, gürültünün azalması, } \\
\text { öğretmenin sesini daha az kullanması ve daha az uyarı yapması) } \\
\text { 3. Öğretmenin kişisel/mesleki performansı (psikolojik açıdan rahatlama, } \\
\text { zihin olarak daha az yorulma, daha sabırlı olma) }\end{array}$ \\
\hline
\end{tabular}

Tablo 8 incelendiğinde, Türk Müziği çocuklara, müziğe karşı estetik alg1 oluşması, dikkati odaklama, dikkat süresini artırma, mantık ve muhakemede gelişme, daha huzurlu ve keyifli çalışma gibi olumlu katkılar sağlamıştır. Sınıf yönetimine, çocukların daha sakin olması, gürültünün azalması, öğretmenin sesini daha az kullanması ve daha az uyarı yapması, Öğretmenin kişisel/mesleki performansına ise psikolojik açıdan rahatlama, zihin olarak daha az yorulma, daha sabırlı olma gibi olumlu katkılar sağlamıştır.

Müzikli Deney Grubu öğretmeni Türk Müziği'ne ilişkin görüşlerini "Çocuklarda müziğe karşı estetik algı oluşturdu. Dikkati odaklama, dikkat süresini artırma, yapılan işi daha kısa sürede bitirme, mantık ve muhakeme gerektiren masa çalışmalarında gelişme gibi gözlemlerim oldu. Daha huzurlu ve keyifli çalıştıklarına, müzik olmadığında çocuklarm bunun eksikliğini hissetmesine ve müzik açılmasmı istemelerine şahit oldum. Sinıfta gürültü azaldr, bunun sonucunda da sinıfta sesimi daha az kullandım ve daha az uyar yaptım. Öğretmen olarak bana daha keyifli ve huzurlu çalışma olanağı sundu, güne müzikle başlamak insanın daha dingin, daha keyifli, daha aktif olmasını sağlıyor ve sizi dinlendiriyor. Zihin olarak daha az yorulduğumu ve daha sabırlı çalıştığımı fark ettim." şeklinde ifade etmiştir. Müzikli Deney Grubu'nun öğretmeni, program süresince dinledikleri eserlerin hem çocuklara hem de kendisine olumlu etkisi olduğunu belirtmiştir.

Tablo 9. Kontrol Grubu Öğretmeninin Görüşleri

\begin{tabular}{|l|l|l|}
\hline \multicolumn{2}{|c|}{ Öğretmen Görüşleri } \\
\hline Soru & \multicolumn{1}{|c|}{ Uygulama Sonrası } \\
\hline $\begin{array}{l}\text { 1.Psikolojik Sağlamlık Ölçeği'ni 1,5 ay sonra tekrar } \\
\text { doldurduk, çocukların puanlarının ön teste göre düşük } \\
\text { olmasını etkileyen faktör nedir? }\end{array}$ & $\begin{array}{l}\text { 1. Covid } 19 \text { (maske, mesafe, temizlik kuralları, } \\
\text { ebeveynlerin tedirginliğinin devamsızlığa } \\
\text { yansıması, motivasyonun azalması, vb.) }\end{array}$ \\
\hline
\end{tabular}


Tablo 9 incelendiğinde, Kontrol Grubu'ndaki çocukların puan düşüklüğüne neden olarak, Covid 19 sürecinde maske-mesafe-temizlik kuralları nedeniyle çocukların rahat hareket edememesi, velilerin tedirgin olmasının devamsızlığa yansıması ve veliler gibi öğretmenin de Covid olma endişesi taşıması nedeniyle motivasyonun azalması şeklinde belirtilmiştir.

Kontrol Grubu öğretmeni son testte çocukların puanlarının düşmesine ilişkin görüşleri: "Çocukların üç saat gibi uzun bir süre maskeli olması, sinufta rahat hareket edememesi, sosyal mesafe I temizlik kurallarına uymaları için sık sık uyarı yapılması, oyuncakların kaldırılması ve daha önceki yillarda yaptığımı grup etkinliklerinin bireysele dönüşmesi, çocuklan olumsuz etkiledi. Pandemi sürecinde velilerin tedirgin olması, çocukların devamsızlık yapmasına neden oldu. Veliler ve çocuklarda olduğu gibi pandemi süreci biz öğretmenleri de olumsuz etkileyerek motivasyonumuzun düşmesine neden oldu." şeklinde ifade etmiştir.

\section{TARTIŞMA ve SONUÇ}

Bu araştırma, Türk Müziği Destekli Psikolojik Sağlamlık Programı́nın okul öncesi dönemdeki çocukların psikolojik sağlamlık düzeylerine etkisinin ortaya konulması amacıyla gerçekleştirilmiştir. Bu bölümde ilgili literatür ışığında araştırma bulguları tartışılmaya çalışılmıştır.

Araştırmaya dahil edilen grupların ön-test puan ortalamaları incelendiğinde Müzikli Deney grubunun ölçeğin görev yönelimi ve keşfetmekten hoşlanma alt boyutlarında anlamlı olmak üzere tüm alt boyutlarında en düşük puana sahip olduğu görülmektedir. Grupların ön-son test puanları incelendiğinde son test puanlarının her iki deney grubunun lehine anlamlı farklılık gösterdiği saptanmıştır. Başka bir ifadeyle uygulanan Psikolojik Sağlamlık Programı'nın çocukların psikolojik sağlamlık düzeylerine anlamlı katkı sunduğu söylenebilir. Bu araştırma bulgularına paralel olarak; Giordano, Ragnoli ve Brajda Bruno (2019), Desteklenmiş Psikolojik Sağlamlık Yaklaşımı Terapisi'nde yer alan bir grup Litvanyalı şiddet mağduru çocuğun terapi sonunda, psikolojik sağlamlık seviyelerindeki artışın, öfke ve ayrışma travmasına bağlı semptomların azaltılması açısından olumlu etkiler sağladığını belirtmektedir. Dufour, Denoncourt ve Mishara (2011), Kuzey Amerika'da çocukların günlük stres ve zorluklarla daha iyi başa çıkabilmeleri için sosyal-duygusal becerileri kazandırmaya yönelik Zippy'nin Arkadaşları Programı'na katılan altı ile yedi yaş arası çocuklarda, azalan içselleştirme, gelişmiş işbirliği, özerklik, sosyal beceri ve algılanan sosyal destek açısından olumlu sonuçlar görülmüştür. Wong (2008), Hong Kong'da Zippy'nin Arkadaşları Programı'na katılan anaokulu çocuklarının daha fazla başa çıkma mekanizması kullandığı, sınıfta akranlarıyla daha iyi iletişim kurduklarını ve duygusal ihtiyaçlarını daha iyi anlamalarına yardımcı olduğunu tespit etmiştir. Lebuffe (2002), psikolojik sağlamlığa katkıda bulunan koruyucu faktörlerin çalışmaya katılan küçük çocuklarda güçlendirilip güçlendirilmediğini araştırdığı çalışmasında programının hem çocukların koruyucu faktörlerini artırmada hem de davranışsal kaygılarını ortadan kaldırmada etkili olduğu saptanmıştır. Israelashvili ve Wegman-Rozi (2003), okul öncesi dönemdeki çocukların psikolojik sağlamlığını geliştirme çabası içeren A.R.Y.A. projesini uyguladıkları çalışmada, projenin çocukların psikolojik sağlamlığını olumlu yönde etkilediği sonucuna ulaşılmıştır. Kuru (2020), okul öncesi dönemdeki mülteci çocuklara yönelik hazırlanan kahkaha yogası programının mülteci çocukların benlik saygısını, sosyal becerisini ve psikolojik sağlamlığını geliştirmede etkili olduğu sonucuna ulaşmıştır. 
Druker, Mazzucchelli ve Beilby'nin (2019), kekemelik tedavisinde psikolojik sağlamlığın bir parçası olarak öz düzenlemeyi ele almanın etkilerini araştırdığı çalışmasında, psikolojik sağlamlık parçasını alan kekeme çocuklarda davranışsal ve duygusal sorunlarda azalma ve psikolojik sağlamlıkta artış gözlenmiştir. De Villers ve Van Den Berg (2012), çocuklar için bir psikolojik sağlamlık programı geliştirmek, uygulamak ve değerlendirmeyi amaçladıkları müdahale programında, duygusal düzenleme ve öz değerlendirme gibi kişisel özelliklerin, çocukların psikolojik sağlamlık programına maruz kaldıktan sonra önemli ölçüde arttı̆̆ını ortaya koymuşlardır. Zhang vd. (2020), okul öncesinde geride kalmış çocuklar (LBC) arasında psikolojik sağlamlık ve duygu düzenleme arasındaki ilişkiyi incelediği çalışmada, duygu düzenleme, okul öncesi LBC arasında psikolojik sağlamlıkla bağdaştırılmış ve duygu düzenlemelerinin güçlendirilmesinin psikolojik sağlamlığ1 teşvik edebileceğini ve LBC'deki olumsuz gelişmeleri önleyebileceğini ileri sürmektedir. Sikorska ve Paluch (2016), çocukların psikolojik sağlamlıkları üzerindeki etkisini incelediği program çalışmasında, çocukların psikolojik sağlamlık göstergelerinde önemli bir değişiklik ve iyileşme olduğunu, girişkenlik, öz-kontrol ve tüm koruyucu faktörlere ilişkin yetkinliklerdeki artış, davranışsal endişelerde ise azalma gözlenmiştir. Olvera (2013), erken çocukluk ruh sağlı̆̆ı konsültasyonu programının erken çocuklukta sosyal ve duygusal eksiklikleri azaltmadaki etkisini incelediği çalışması, girişkenlik, öz-kontrol, bağlanma ve toplam koruyucu faktörlerde önemli artşlarla birlikte davranışsal endişelerde önemli azalmalar olduğunu göstermiştir. Araştırmanın nitel bulguları da nicel bulguları destekler niteliktedir. Araştırmanın nitel boyutunda deney grubu öğretmenleri, psikolojik sağlamlık programının; çocuklarda iletişim kurma becerisi, kurallara uyma, nezaket, saygı, öz-kontrol, empati, sabırlı olma, soru sorma, girişken olma, cesaret, pes etmeme, problem çözme, muhakeme etme gibi beceriler kazandırmada, duygularını daha iyi ifade edebilme ve kontrol edebilme, öfke kontrolü, stresle başa çıkma becerilerine programın olumlu katkısı bulunduğunu ifade etmişlerdir. Söz konusu beceriler psikolojik sağlamlığın yapı taşları olması nedeniyle önemli görülmektedir.

Araştırmada Müzikli ve Müziksiz Deney Grubu son test puanları arasındaki farkın Müzikli Deney Grubu lehine olduğu saptanmıştır. Bu araştırma bulgusuna paralel olarak; Jucan ve Simion (2015)'e göre, müzik herkes tarafından ulaşılabilir olsa da, okul öncesi çocukların hayatında, anaokulunda ve ayrıca evde önemli bir yer tutmalıdır. Müzik evrensel bir dildir ve erken yaşlardan beri çocuklar için erişilebilir ve okul öncesi dönemde disiplinler arası beceri gelişiminin önemli bir unsuru olabilir. Yazıcı (2017), müzik ve beyin arasındaki ilişkiyi incelediği çalışmasında, müzik eğitiminin beyindeki yeni ve sürekli bağlantilar oluşumunu canlandırdığını saptamıştır. Ünal (t.y.) çalışmasında, otonom sinir sistemine etkisi ispatlanan müziğin kişiye göre anlamını; bireyin yaşama ve olaylara bakışını etkileyen ve çocuklukta oluşan bilişsel şemalar, duygusal yaşantılar, geçmişteki deneyimler, kültürel bakış açısı, müzik eğitimi ve eğilimi gibi bir dizi faktör oluşturduğunu belirtmiştir. Sezince (2018), 3-6 yaş çocuklarda müzik ve dans eğitiminin motivasyon, fiziksel ve psikolojik etkilerini araştırdığ çalışmasında, dans terapi yöntemlerinin çocukların motivasyon, fiziksel ve psikolojik gelişimlerini arttırdığı bulunmuştur. Love ve Bums (2007), 3-5 yaş grubu bir okul öncesi sinıfında, blok oda içinde farklı tempolardaki fon müziğinin sosyodramatik oyun ve yapıcı oyun üzerindeki etkisini incelediği çalışmada, fon müziği varken çocukların blok odaya fon müziği olmadan giriş çıkış oranlarına göre \%50 daha az girip çıktıkları bulunmuştur. Bu bulguyu, müziğin dikkat ve sosyal etkileşimler üzerindeki etkisi olarak belirtmişlerdir. Mattar 
(2013), Mozart müziğinin beş ve altı yaşındaki çocukların sosyal, bilişsel ve fiziksel gelişimine etkisini araştırdığı çalışmada, Mozart müziğinin sosyal, bilişsel ve fiziksel alanlardaki gelişimi önemli ölçüde etkilediği ayrıca çocukların vücutlarını hareket ettirmelerini sağladığı, kendilerini fiziksel olarak ifade ederek, yeni bilgilerle bütünsel yollarla çalıştıklarını tespit etmiştir. Jucan ve Simion (2015), okul öncesi çocuklarda arka planda müzik dinlemenin sosyalduygusal gelişime etkisini incelediği çalışmada, incelenen tüm sosyal-duygusal becerilerin gelişiminde artış gözlemlenmiş olup, müzik dinleme etkinliklerin gelişimini olumlu yönde etkileyerek, okul öncesi çocukları teşvik etmeyi başarmıştır. Araştırmada Müzikli Deney Grubu'nun uygulanan program sonrasında; Müziksiz Deney Grubu'na göre anlamlı derecede düşük olan puan farkını ortadan kaldırması; bazı alt ölçeklerde kendi lehine anlamlı farklılık yaratması; betimsel analizler incelendiğinde 1. deney grubuna göre kendi içindeki puan artışının daha fazla olması gibi sonuçlar programa entegre edilen Türk Müziğinin olumlu etkisi olarak değerlendirilmektedir. Araştırmanın nitel bulguları da bu sonucu destekler niteliktedir. Müzikli Deney Grubu öğretmeni programla birlikte müzik kullanılmasının, müziğe karşı estetik algı oluşması, iletişim kuramayan öğrencilerin müziğin ritmine bedenini hareket ettirerek cevap vermesi, dikkati odaklama, yapılan işi daha kısa sürede bitirme, daha huzurlu ve keyifli çalışma gibi psikolojik sağlamlığı güçlendiren beceriler üzerinde olumlu katkıları olduğunu belirtmiştir.

Araştırma sonucunda Kontrol Grubu'ndaki çocukların ön-son test puanları arasındaki farkın son test lehine azaldığı saptanmıştır. Puan düşüklüğünün sebebi incelendiğinde ilk dikkat çeken etken olarak pandemi süreci düşünülebilir. Covid 19, milyonlarca insanı etkileyen ve yayılarak tüm dünyayı etkisi altına alan bir salgın hastalık olarak belirtilmektedir. Veriler, tüm dünyada olduğu gibi ülkemizde de aylardır devam eden Covid-19 salgınının insanları etkilediğini göstermektedir (WHO, 2021; Sağlık Bakanlığ1, 2021). Erol ve Erol (2020), koronavirüs pandemisi sürecinde öğrencilerin ve ebeveynlerin korkulu-kaygll hissettiklerini belirtmiştir. Tönbül (2020) yaptığı araştırmada, pandemi sonrası bireylerin içinde bulundukları fiziksel ve ruhsal durumun psikolojik sağlamlığı etkilediği bulunmuştur. Bilge ve Bilge (2020), koronavirüs salgını ve sosyal izolasyonun ve stresle işlevsel olmayan başa çıkmanın bireylerin psikolojik semptomlarında bozucu bir etki oluştururken psikolojik sağlamlığın ise koruyucu bir etkisi olduğunu belirtmiştir. Cusinato, Iannattone, Spoto, Poli, Moretti, Gatta ve Miscioscia (2020) Covid-19 sürecinde ebeveyn stresini ve çocukların psikolojik sağlamlıklarını araştırdıkları çalışmada, salgının ebeveynlerin psikolojilerini olumsuz yönde etkilediğini, dolayısıyla çocukları iyi oluşları için önemli bir riske maruz bıraktığını ve çocuklarda daha düşük psikolojik sağlamlık seviyeleri tespit edildiğini belirtmiştir. Spinelli, Lionetti, Pastore ve Fasolo (2020), Covid-19 salgını deneyimiyle ilişkili risk faktörlerinin 2-14 yaş arası çocuğu olan ebeveynler ve çocuklarının iyi oluşu üzerindeki etkisini araştırdığ1 çalışmada, sonuçlar; karantinanın stres algısının hem ebeveynleri hem de çocukların iyi oluşunu olumsuz etkileyen çok önemli bir faktör olduğunu kanıtlamıştır. Yapılan literatür incelemesinde, kontrol grubunun Psikolojik Sağlamlık Ölçeği'nden aldıkları puanlara ilişkin deney öncesi ve sonrası durumlarına göre; alt boyutlarından aldıkları puanların ön test lehine olmasını destekler nitelikte araştırmalar olduğu görülmektedir. Araştırmanın nitel bulguları da bu düşünceyi destekler niteliktedir. Kontrol Grubu öğretmeni, pandemi nedeniyle çocukların maskeli olması, rahat hareket edememesi, velilerin tedirgin olması nedeniyle çocukların devamsızlık yapması gibi gerekçelerin psikolojik sağlamlık puanlarında düşüşe neden olabileceğini 
belirterek, Covid kapsamında maske, mesafe, temizlik gibi alınan tedbirlerin çocukların etkileşimlerini olumsuz yönde etkilediği ifade edilmiştir.

Çocukların ve yetişkinlerin psikolojilerinin olumsuz etkilendiği, kaygı boyutlarının arttığı Pandemi döneminde, Müzik Destekli Psikolojik Sağlamlık Programı Covid-19'un olumsuz etkilerini azaltarak çocukların psikolojik sağlamlık düzeylerine olumlu katkı sağlamıştır. Türk müziğinin de Psikolojik Sağlamlık Programı üzerindeki etkisinin önemli rol oynadığ görülmektedir. Diğer taraftan psikolojik olarak sağlam çocukların özellikleri incelendiğinde, etkili iletişim becerisine sahip, özgüvenli, mizah yapabilen, yeni arkadaşlıklar kurabilen, duygularını ifade edebilen, stresle baş edebilen, etkili problem çözebilen, muhakeme becerileri yüksek, empati kurabilen, öz-disiplin/öz-kontrol becerilerine sahip, yeni fikirlere açı, soru soran, kaybetmenin yada hata yapmanın önemli olmadığının bilincinde, karşılaştığ zorluklarda pes etmeden çözüm yollarını deneyebilen, sabırlı, haksızlığa uğradığında hakkını arayabilen, günlük yaşamlarında daha mutlu ve iyimser oldukları görülmektedir. Dolayısıyla sosyal duygusal gelişimi destekleyen programların çocukların bu özelliklerini destekleyerek psikolojik sağlamlık düzeylerine olumlu katkı sağladığı, Türk müziğinin ise bu etkiyi artırmada etkin bir rol oynadığı saptanmıştır.

Bu çalışma, okul öncesi dönemde Türk müziği desteği ile psikolojik sağlamlığın desteklenebileceğini ortaya koyan ilk verileri sağlamaktadır. Pandemi nedeniyle çocuk sayılarının eşitlenmesi mümkün olamamıştır. Program uygulaması 10 hafta, haftada 3 gün olarak planlanmışken, 4 hafta haftanın 5 günü uygulanmıştır. Uzaktan eğitime geçilmesi nedeniyle 30 etkinlikten 22'si uygulanabilmiştir. Bu sınırlılıklara rağmen, kısa sürede olumlu sonuçlar alınmıştır. Okul öncesi öğrencilerinin dayanıklılık geliştirmelerine ve sosyal-duygusal gelişimlerinin desteklenmesine olanak sağlayan uygulamalara ilişkin anlayışların ve algıların ortaya çıkmasına izin veren ilk çalışma olarak gelecekte yapılacak olan çalışmalara ışık tutacağ düşünülmektedir. Araştırmanın bulguları ışığında aşağıdaki öneriler verilebilir;

- Okullar, dünyanın sunduğu her şeyi hararetle kucaklayan öğrencileri yetiştirme ve bu öğrencilerin toplumumuza ve ülkemize katkıda bulunan vatandaşlar olmaları için ihtiyaç duyacakları beceri ve yetenekleri geliştirmekle görevlidirler. Psikolojik sağlamlık eğitiminin verilmesi ile olumsuz duygular/davranışlar, pandemi gibi olumsuz yaşam koşullarının olumsuz etkilerinden çocukları koruyacağı düşünülerek öğretmenlerin çocukların psikolojik sağlamlık eğitimini nasıl verecekleri konusunda desteklenerek gerekli rehberliği almaları sağlanabilir.

- Türk Müziği Destekli Psikolojik Sağlamlık Programı alandaki ilk çalışma olması nedeniyle, Psikolojik Sağlamlık Programı'nın yaygınlaştırılması, sosyal-duygusal temelli eğitim programlarına, MEB programlarına entegre edilerek etkisi incelenebilir.

- Psikolojik sağlamlık pedagojisi için kasıtlı planlama yoluyla çocukları riskten korumak için okulların sorumluluk üstlenmesi bu alanda program uygulamalarının yapılması sağlanabilir.

- Pandemi sürecinde uygulanan Türk Müziği Destekli Psikolojik Sağlamlık Programı́nın olumlu etkileri görülmüştür. Bu nedenle bu program farklı travma dönemlerinde önlem yada müdahale programı olarak kullanılabilir.

- Okul öncesi eğitim kurumlarında "Aile katılımlı Türk Müziği Destekli Psikolojik Sağlamlık Programları" yapılabilir. 
- "Türk Müziği Destekli Psikolojik Sağlamlık Aile Eğitim Programları" hazırlanabilir, programın aile tutumlarına, çocuklara etkisi incelenebilir.

- Sinıf ortamlarında, Türk müziğinin koruyucu bir faktör olarak özel rolü veya müziğin insan yaşamındaki benzersiz rolü hakkında yeni araştırmalar yapılabilir

- Türk müziği yerli ya da yabancı diğer psikolojik sağlamlık programlarının farklı yaş gruplarındaki etkisinin değerlendirilmesi amaçlı kullanılabilir.

- Araştırma Tokat il merkezinde bulunan Milli Eğitim Bakanlığına bağlı resmi ilkokulların anasınıfına devam eden 48-72 aylık çocuklar ile gerçekleştirilmiştir. Farklı illerde, farklı yaş grupları ve farklı kurumlardaki çocuklarla da bu çalışma gerçekleştirilebilir.

\section{KAYNAKÇA}

Alkaya Yener, Y. (2011). Müziğin çocuklar ve yaşlılar üzerindeki etkileri. Pamukkale Üniversitesi Eğitim Fakültesi Dergisi, 29(1), 119-124.

Alvord, M. K. ve Grados, J. J. (2005). Enhancing resilience in children: A proactive approach. Professional Psychology: Research and Practice, 36, 238-245.

Andreasen, N. C. (2015). Yaratıcı beyin. (Çev. K. Güney). Ankara: Akılçelen Kitaplar.

Bailey, C. S., Zinsser, K. M., Curby, T.W., Denham, S.A. ve Bassett, H.H. (2013). Consistently emotionally supportive preschool teachers and children's social-emotional learning in the classroom: Implications for center directors and teachers. Dialog, 16(2), 131-137.

Belgin, E. (2014). Müzik ve beyin (Makam, ritim bileşkesi, alg1 ve duygu etkileri).. Yeni Türkiye Dergisi (Özel Sayı), 10(57), 1346-1348.

Benard, B. (1993). Fostering resiliency in kids. Educational Leadership, 51(3), 44-48.

Bilge, Y. ve Bilge, Y. (2020). Koronavirüs salgını ve sosyal izolasyonun psikolojik semptomlar üzerindeki etkilerinin psikolojik sağlamlık ve stresle baş etme tarzları açısından incelenmesi. Klinik Psikiyatri Dergisi, 23(Ek 1), 38-51.

Büyüköztürk, Ş., Çakmak, E. K., Akgün, Ö. E., Karadeniz, Ş. ve Demirel, F. (2017). Bilimsel araştırma yöntemleri. Ankara: Pegem.

Campbell, P.S., Connell, C. ve Beegle, A. (2007). Adolescents' expressed meanings of music in and out of school. Journal of Research in Music Education, 55(3), 220-236.

Creswell, W. (2017). Karma yöntem araştırmalarına giriş. (Çev. M. Sözbilir,). Ankara: Pegem.

Cusinato, M., Iannattone, S., Spoto, A., Poli, M., Moretti, C., Gatta, M. ve Miscioscia, M. (2020). Stress, resilience, and well-being in Italian children and their parents during the COVID 19 pandemic. International Journal of Environmental Research and Public Health, 17, 8297.

De Villers, M. ve Van Den Berg, H. (2012). The implementation and evaluation of a resiliency programme for children. South African Journal of Psychology, 42(1), 93-102. 
Druker, K., Mazzucchelli, T.G. ve Beilby, J. (2019). An evaluation of integrated fluency and resilience program for early developmental stuttering disorders. Journal of Communication Disorders, 78, 69-83.

Dufour, S., Denoncourt, J. ve Mishara, B.L. (2011). Improving children's adaptation: New evidence regarding the effectiveness of Zippy's Friends, a school mental health promotion program. Advances in School Mental Health Promotion, 4(3), 18-28.

Dumont E., Syurina E.V., Feron F.J.M. ve van Hooren, S. (2017). Music interventions and child development: A critical review and further directions. Frontiers in Psychology, 8, 1694.

Ekici, S. (2014). Türk müziğinde makamlar ve tedavi. Yeni Türkiye Dergisi (Özel Sayı)., 10(57), 1361-1369.

Erol, M. ve Erol, A. (2020). Koronavirüs pandemisi sürecinde ebeveynleri gözünden ilkokul öğrencileri. Milli Ĕ̆itim Dergisi (Özel Sayı), 49(1), 529-551.

Garmezy, N. ve Masten, A. S. (1986). Stress, competence and resilience: common frontiers for therapist and psychopathologist. Behavior Therapy, 17, 500-521.

Gençel, Ö. (2006). Müzikle tedavi. Kastamonu Ĕ̆itim Dergisi, 14(2), 697-706.

Giordano, F., Ragnoli, F. ve Brajda Bruno, F. (2019). Data on resilience and trauma-related symptoms in Lithuanian children victims of violence. 4 Nisan 2021 tarihinde https://www.sciencedirect.com/science/article/pii/S2352340919301428 adresinden erişildi.

Güvenç, R.O. (2014). Eski Türklerde müzik ile tedavi. Yeni Türkiye Dergisi (Özel Sayı), 10(57), 1327-1337.

Henderson Grotberg, E. (2001). Resilience programs for children in disaster. Ambulatory Child Health, 7(2), 75-83.

Israelashvili, M. ve Wegman-Rozi, O. (2003). Advancement of preschoolers' resilience: The A. R.Y.A. project. Early Childhood Education Journal, 31(2), 101-105.

Jucan, D. ve Simion, A. (2015). Music background in the classroom: Its role in the development of social-emotional competence in preschool children. Procedia - Social and Behavioural Sciences, 180, 620-626.

Kalender, R. (1998). Musiki ve insan. Ankara Üniversitesi İlahiyat Fakültesi Dergisi, 37, 240-244.

Kordich Hall, D. ve Pearson, J. (2005). Resilience - giving children the skills to bounce back. Education and Health, 23(1), 12-14.

Kuru, N. (2020). Tamamlayıcı erken müdahale programınm mülteci çocuklarm benlik saygısına, sosyal becerilerine ve psikolojik sağlamlığına etkisi. Yayımlanmamış doktora tezi, Hacettepe Üniversitesi Eğitim Bilimleri Enstitüsü, Ankara.

LeBuffe, P. A. (2002). Can we foster resilience? An evaluation of a prevention program for preschoolers. Conference proceedings of the 15th annual conference of a system of care for children's mental health: Expanding the Research Base. 4 Nisan 2021 tarihinde https://files.eric.ed.gov/fulltext/ED477671.pdf adresinden erişildi. 
Love, A. ve Burns, M. S. (2007). It's a hurricane! It's a hurricane!: Can music facilitate social constructive and sociodramatic play in a preschool classroom? The Journal of Genetic Psychology, 167(4), 383-391.

Maier, M.F., Vitiello, V.E. ve Greenfield, D.B. (2012). A multilevel model of child- and classroom-level psychosocial factors that support language and literacy resilience of children in Head Start. Early Childhood Research Quarterly, 27(1), 104-114.

Masten, A.S. (2014). Ordinary magic: Resilience in development. New York: Guilford Press.

Masten, A.S. (2019). Resilience from a developmental systems perspective. World Psychiatry, 18(1), 101-102.

Masten, A.S. ve Barnes, A.J. (2018). Resilience in children: Developmental perspectives. Children, 5(7), 98.

Masten, A.S., Best, K. ve Garmezy, N. (1990). Resilience and development: Contributions from the study of children who overcome adversity. Development and Psychopathology, 2(4), 425-444.

Masten, A.S. ve Coatsworth, J.D. (1998). The development of competence in favorable and unfavorable environments lessons from research on successful children. 4 Nisan 2021 tarihinde https://www.researchgate.net/publication/13739433 adresinden erişildi.

Masten, A.S., Gewirtz, A.G. ve Sapienza, J.K. (2013). Resilience in development: The importance of early childhood. 15 Nisan 2021 tarihinde https://www.childencyclopedia.com/sites/default/files/dossiers-complets/en/resilience.pdf_adresinden erişildi.

Mattar, J.W. (2013). The Effect of Mozart's Music on Child Development in a Jordanian Kindergarten. 6 Temmuz 2021 tarihinde https://www.researchgate.net/publication/276275115 adresinden erişildi.

Mihaelaa, T.I. (2015). Promoting the emotional wellbeing of preschoolers. Social and Behavioral Sciences, 209, $509-513$.

Miljević-Ridički, R., Plantak, K. ve Bouillet, D. (2017). Resilience in preschool children - The perspectives of teachers, parents and children. International Journal of Emotional Education, $9(2), 31-43$.

Newman, T. ve Blackburn, S. (2002). Transitions in the lives of children and young people: Resilience factors. Edinburgh: Scottish Executive Education Department.

Oades-Sese, G.V., Cohen, D., Allen, J.W.P. ve Lewis, M. (2014). Building resilience in young children the sesame street way. S. Prince-Embury \& D.H. Saklofske (Eds.). Resilience Interventions for Youth in Diverse Populations içinde. 181-201. New York, NY: Springer. https://doi.org/10.1007/978-1-4939-0542-3 9.

Olvera, L. (2013). Early childhood mental health consultation programs and the effect on protective factors and behavioral concerns of preschool children. Yayımlanmamış doktora tezi, Walden University College of Social and Behavioral Sciences, USA. 
Osofsky, J. D. ve Osofsky, H. J. (2018). Challenges in building child and family resilience after disasters. Journal of Family Social Work, 21(2), 115-128.

Özbey, S. (2019). Okul öncesi çocuklar için sosyal duygusal iyi oluş ve psikolojik sağlamlık ölçeğinin (PERIKK) geçerlik güvenirlik çalışması, Uluslararası Toplum Araştırmaları Dergisi, 10(17).

Petty, K. (2014). Ten ways to foster resilience in young children - Teaching kids to "bounce back". Dimensions of Early Childhood, 42(3), 35-39.

Price, B.J. (2011). Resilience among high achievers in an instrumental music program. Yayımlanmamış yüksek lisans tezi, University of North Texas, USA.

Sağlık Bakanlığı, (2021). Türkiye günlük koronavirüs tablosu. 4 Nisan 2021 tarihinde https://covid19.saglik.gov.tr/TR-66935/genel-koronavirus-tablosu.html adresinden erişildi.

Schilling, D. (2009). Duygusal zekâ beceri eğitimi uygulamaya yönelik pratik bir model ve 50 aktivite. Ankara: Maya Akademi Yayınları.

Sezince, M. (2018). 3-6 yaş çocuklarda müzik ve dans eğitiminin psikolojik etkileri. Yayımlanmamış yüksek lisans tezi, İstanbul Aydın Üniversitesi Sosyal Bilimler Enstitüsü, İstanbul.

Sikorska, I. ve Paluch, M. (2015). Brave children: How to develop resilience in childhood. 15 Nisan 2021 tarihinde https://www.researchgate.net/publication/306218967 adresinden erişildi.

Snyder, S. (1997). Developing musical intelligence: Why and how. Early Childhood Education Journal, 24(3), 165-171.

Spinelli, M., Lionetti, F., Pastore M. ve Fasolo, M. (2020). Parents' stress and children psychological problems in families facing the COVID-19 outbreak in Italy. Frontiers in Psychology, 11, 1713.

Tönbül, Ö. (2020). Koronavirüs (Covid-19) salgını sonrası 20-60 yaş arası bireylerin psikolojik dayanıklılıklarının bazı değişkenler açısından incelenmesi. Uluslararası Akademik Psikolojik Danışma ve Rehberlik Araştırmaları Dergisi, 2(2), 159-174.

Twenge, J. M. (2013). Ben nesli. (Çev. E. Öztürk). İstanbul: Kaknüs.

Uluğbay, S. (2013). Müzik eğitiminin çocuk zekâsına olan etkileri. Kastamonu Eğitim Dergisi, 21(3), 1025-1034.

Ünal, F. S. (t.y.). Geleneksel müziğimizin insan sağlı̆ğ üzerindeki olumlu etkisi ve müzikle tedavi. 15 Nisan 2021 tarihinde https://docplayer.biz.tr/4735471-Geleneksel-muzigimizininsan-sagligi-uzerindeki-etkisi-ve-muzikle-tedavi.html adresinden erişildi.

Werner, E. E. (1993). Risk, resilience and recovery: Perspectives from the Kauai longitudinal study. Development and Psychopatholog, 5, 503-15.

Werner, E. E. (1997). Vulnerable but invincible: High-risk children from birth to adulthood. Acta Piediatr, 422, 103-105.

Wong, M. (2008). Helping young children to develop adaptive coping strategies. Journal of Basic Education, 17(1), 119-44. 
World Health Organization (WHO) (2021). WHO Coronavirus Disease (covid-19) Dashboard. 4 Nisan 2021 tarihinde https://covid19.who.int/ internet adresinden erişildi.

Yazıc1, D. (2017). Müziğin insan beyni üzerindeki etkisi. Uluslararası Kültürel ve Sosyal Araştırmalar Dergisi (UKSAD), 3(1), 88-103.

Yıldırım, A. ve Şimşek, H. (2011). Sosyal bilimlerde nitel araştırma yöntemleri. Ankara: Seçkin.

Yule, K. (2017). Caregivers' role in fostering resilience in preschoolers. 4 Nisan 2021 tarihinde http://epublications.marquette.edu/theses open/427 adresinden erişildi.

Zhang, J., Wu, Y., Qu, G., Wang, L., Wu, W., Tang, X., Liu, H., Chen, X., Zhao, T., Xuan, K. ve Sun, Y. (2020). The relationship between psychological resilience and emotion regulation among preschool left-behind children in rural China. Psychology, Health $\mathcal{E}$ Medicine, https://doi.org/10.1080/13548506.2020.1849748. 